\title{
An Immunological Perspective of Circulating Tumor Cells as Diagnostic Biomarkers and Therapeutic Targets
}

\author{
Eunice Dotse ${ }^{1,+}$, King H. Lim ${ }^{1,+}$, Meijun Wang ${ }^{1,+}$, Kevin Julio Wijanarko ${ }^{2,3,+} \mathbb{D}$ and Kwan T. Chow ${ }^{1, * \mathbb{D}}$ \\ 1 Department of Biomedical Sciences, City University of Hong Kong, Hong Kong 999077, China; \\ edotse2-c@my.cityu.edu.hk (E.D.); kinglim4-c@my.cityu.edu.hk (K.H.L.); meijwang-c@my.cityu.edu.hk (M.W.) \\ 2 Department of Paediatrics, University of Melbourne, Parkville, VIC 3010, Australia; \\ kwijanarko@student.unimelb.edu.au \\ 3 Murdoch Children's Research Institute, Royal Children's Hospital, Parkville, VIC 3052, Australia \\ * Correspondence: ktchow@cityu.edu.hk \\ + These authors contributed equally to this work.
}

Citation: Dotse, E.; Lim, K.H.; Wang, M.; Wijanarko, K.J.; Chow, K.T. An Immunological Perspective of Circulating Tumor Cells as Diagnostic Biomarkers and Therapeutic Targets. Life 2022, 12, 323. https://doi.org/10.3390/life12020323

Academic Editor: Marisa Colone

Received: 26 January 2022

Accepted: 14 February 2022

Published: 21 February 2022

Publisher's Note: MDPI stays neutral with regard to jurisdictional claims in published maps and institutional affiliations.

Copyright: (C) 2022 by the authors. Licensee MDPI, Basel, Switzerland. This article is an open access article distributed under the terms and conditions of the Creative Commons Attribution (CC BY) license (https:// creativecommons.org/licenses/by/ $4.0 /)$.

\begin{abstract}
Immune modulation is a hallmark of cancer. Cancer-immune interaction shapes the course of disease progression at every step of tumorigenesis, including metastasis, of which circulating tumor cells (CTCs) are regarded as an indicator. These CTCs are a heterogeneous population of tumor cells that have disseminated from the tumor into circulation. They have been increasingly studied in recent years due to their importance in diagnosis, prognosis, and monitoring of treatment response. Ample evidence demonstrates that CTCs interact with immune cells in circulation, where they must evade immune surveillance or modulate immune response. The interaction between CTCs and the immune system is emerging as a critical point by which CTCs facilitate metastatic progression. Understanding the complex crosstalk between the two may provide a basis for devising new diagnostic and treatment strategies. In this review, we will discuss the current understanding of CTCs and the complex immuneCTC interactions. We also present novel options in clinical interventions, targeting the immune-CTC interfaces, and provide some suggestions on future research directions.
\end{abstract}

Keywords: circulating tumor cells (CTCs); metastasis cascade; immune cells; immune system; immunotherapy

\section{Introduction}

Circulating tumor cells (CTCs) are a heterogeneous population of tumor cells that have shed from a tumor into the lymphatics and vasculature, ultimately disseminating into blood circulation [1]. They have been increasingly studied in recent years due to their clinical relevance. As a component of liquid biopsies, CTCs are important for diagnosis, prognosis, and monitoring treatment responses [2]. Currently, CTCs are the only cell type with commercially available assays approved for use in cancer-related treatment decisions [3]. Beyond their clinical significance, CTCs offer a platform for transcriptomics, genomics, and proteomic studies to provide valuable information on cancer resistance mechanisms [4]. Studies on CTCs have broadened our understanding on intra-tumor heterogeneity, invasion, metastasis tropism, and immune evasion mechanisms [5].

Interplay between CTCs and the immune system has steadily attracted research interest for its emerging utility in predicting treatment outcomes [6].

Notably, CTCs express immune checkpoint regulators and markers that can aid them in evading immune surveillance and alter immune response to improve odds for CTCs survival and metastasis $[7,8]$. In light of this, further exploration in CTC-immune crosstalk will allow for a better grasp in understanding how CTCs respond towards treatments such as immunotherapy. Ultimately, this will be beneficial for devising novel strategies and interventions to monitor and target immune response against CTCs, contributing to the curb against disease recurrence and metastatic spread. 
No doubt, the immune system plays a vital role in tumorigenesis, and CTCs have been known to interact with immune cells in circulation, where they must evade or suppress immune surveillance. This interaction modulates the capacity of CTCs to facilitate metastatic progression. Therefore, understanding the complex immune-CTC crosstalk may provide a basis for designing new treatment strategies.

In this review, we discuss the clinical relevance of CTCs as targets and biomarkers in cancer therapy. We review the crosstalk between CTCs and different immune cell types and highlight the various mechanisms employed by CTC-immune cell clusters to facilitate the metastasis process. We further accentuate the technological advances in CTC isolation and detection strategies, discussing challenges associated with current methods and emphasizing recent efforts for CTC analysis to understand their complexity and heterogeneity. This review provides a forward outlook for scientists and clinicians to address key aspects of CTC-immune interactions that can be harnessed for disease management and treatment.

\section{Circulating Tumor Cells}

Circulating tumor cells were first observed in a metastatic cancer patient by Thomas Ashworth in the mid-nineteenth century $[9,10]$. They are round in shape and range from 12 to $25 \mu \mathrm{m}$ in size [11]. Circulating tumor cells express epithelial cell adhesion molecule (EpCAM) and/or cytokeratins (CK), stem cell-like markers, and lack panleukocyte marker CD45 [12,13]. They are fragile and rare [14] (5-50 CTCs in $7.5 \mathrm{~mL}$ blood) [15], with a half-life of less than $2.5 \mathrm{~h}$ in circulation $[16,17]$. Yet it has been shown that only few CTCs are required to survive the harsh conditions in the bloodstream and extravasate to seed secondary tumors [18-20]. While most CTCs exist in single form, some move as multicellular clusters and can be homotypic or heterotypic [21,22]. Circulating tumor cell clusters in circulation are known to offer survival advantages, with greater metastatic propensity in both human and animal models [21,23].

\subsection{Single CTCs and CTC Clusters}

Single CTCs and clusters are found to have different properties. Single CTCs are derived from a single migratory cell progeny, whereas CTC clusters, found in patients with solid tumors, are of oligoclonal origin [21]. These CTC clusters express more mesenchymal than epithelial markers, as compared to single CTCs [19]. In circulation, CTC clusters make up only $2-4 \%$ of the total CTC population but are 50 times more capable of forming metastatic lesions than single CTCs [21,24]. Circulating tumor cell clusters exhibit embolus/thrombus-like behavior in circulation, with much slower flow rate than single CTCs [24]. Morphologically, CTC clusters are irregular [25], and the size of individual cells within the clusters is smaller than single CTCs [26]. The junctional cell-cell protein plakoglobin is highly expressed in CTC clusters [21]. Studies have indicated that CTC clusters are transcriptionally activated, and hypomethylation of transcription factors that regulate genes associated with proliferation and stemness has been reported [27].

\subsection{CTC and Immune Cell Clusters}

Association of CTCs with immune cells has been shown to increase their metastatic potential by enhancing viability and fostering proliferation $[22,28]$. Neutrophils are among immune cell populations that form clusters with CTCs, through vascular cell adhesion protein 1 (VCAM-1)-dependent intercellular junctions. The CTC-neutrophil clusters express genes that drive cell-cycle progression [22]. Interaction between CTCs and neutrophils occurs within the primary tumor microenvironment before detachment into the bloodstream [22,29]. Cluster formation between CTCs and polymorphonuclear myeloid-derived suppressor cells (PMN-MDSC) has also been reported. Of note, MDSC infiltrates within the tumor microenvironment, promotes tumor growth and inhibits cytotoxic T-cell activity. In circulation, PMN-MDSCs interact directly with CTC to augment dissemination and metastasis by utilizing Notch-Nodal signaling pathway [29]. Circulating tumor cells have also 
been found to interact with platelets minutes before their dissemination [30]. Circulating tumor cells express thrombin to induce platelet aggregation (cloaking), which promotes arrest in the vasculature and facilitates extravasation from vessel walls [31]. Additionally, cloaking offers CTCs protection from fluid shear stress during initial entry into circulation $[32,33]$. Circulating tumor cells are also known to interact with other immune cells, such as monocytes [34,35], fibroblast [36] and macrophages [11,37,38].

\subsection{Tumor-Derived Circulating Hybrid Cells}

Tumor-derived hybrid cells (CHCs) formed by cell fusion have been found in the tumor microenvironment and circulation [39]. Cell fusion is the combination of homotypic or heterotypic cells into a single cell, with shared cytoplasmic and nuclear contents [40]. Tumor-derived hybrid cells co-express pan-leukocyte antigen CD45 and tumor markers, indicating that leukocytes are a fusion partner with tumor cells [39]. Among leukocyte populations, macrophages are the major fusogenic cell type in both mouse and human studies [41]. Accordingly, most CHCs express macrophage markers. Studies have shown an upregulation of genes in pathways associated with metastasis, including RUNX1, leukocyte cell adhesion molecule, and FLT4, in these hybrids [42]. Tumor-derived hybrid cells are more common in circulation than single CTCs and retain all functional attributes (genotypic and phenotypic) of the parent cells. They are also known to be highly migratory and invasive, and enhance chemotherapy resistance [39,43].

\subsection{Cancer-Associated Macrophage-like Cells}

While not considered CTCs, cancer-associated macrophage-like cells (CAMLs) are a circulating stromal cell subtype found in the peripheral blood of patients with different solid cancers [44]. These cells are polynucleated and highly differentiated with vacuoles containing tumor material [11]. They are large with varying morphology and range from 25 to $300 \mu \mathrm{m}$ in size ${ }^{40}$. The CAMLs are postulated to originate from tumor-associated macrophages (TAMs) that have undergone macrophage-macrophage fusion and internalized dying tumor cells before reentering circulation [11]. Cancer-associated macrophagelike cells are known to express a typical macrophage antigen (CD14) and are distinguished from CTCs by their CD45 positivity [39,45]. Unlike CHCs, CAMLs retain their immune cell identity [39]. Like CTCs, the number of CAMLs increase with disease progression [46].

\section{Metastatic Cascade: Crosstalk between CTCs and the Immune System in Non-Tumor Microenvironment}

Circulating tumor cells are a key player in cancer metastasis, a multi-step and complex process that involves (1) local invasion of primary tumor cells into adjacent tissue; (2) intravasation (trans-endothelial migration into nearby blood vessels); (3) circulation (transient travel and survival in the circulatory system as CTCs); (4) extravasation (CTC migration out of the circulatory system followed by seeding in distant organs); (5) colonization (CTC proliferation and growth at seeding sites, eventually becoming clinically detectable metastatic tumors [47-49]) (Figure 1). To successfully metastasize, CTCs must evade immune surveillance at every step once they leave the immunosuppressive tumor microenvironment. On the other hand, immune cells can promote or inhibit tumorigenesis, depending on the cell type and context [50]. We hereby focus on the association of immune factors to the metastasis process and highlight the current understanding and unresolved issues in the field. 

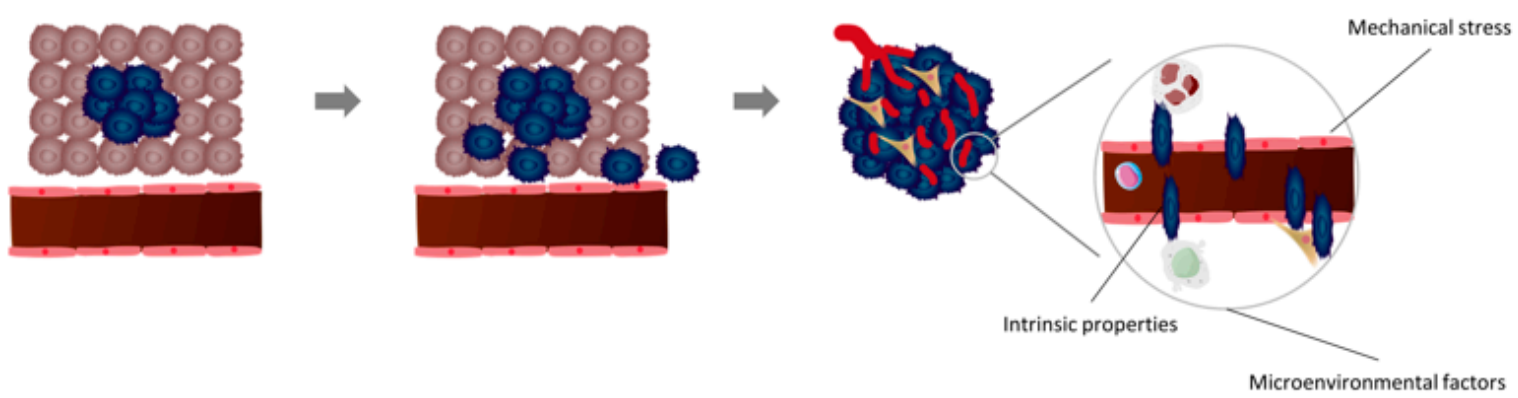

\section{Extravasation \& Colonization}

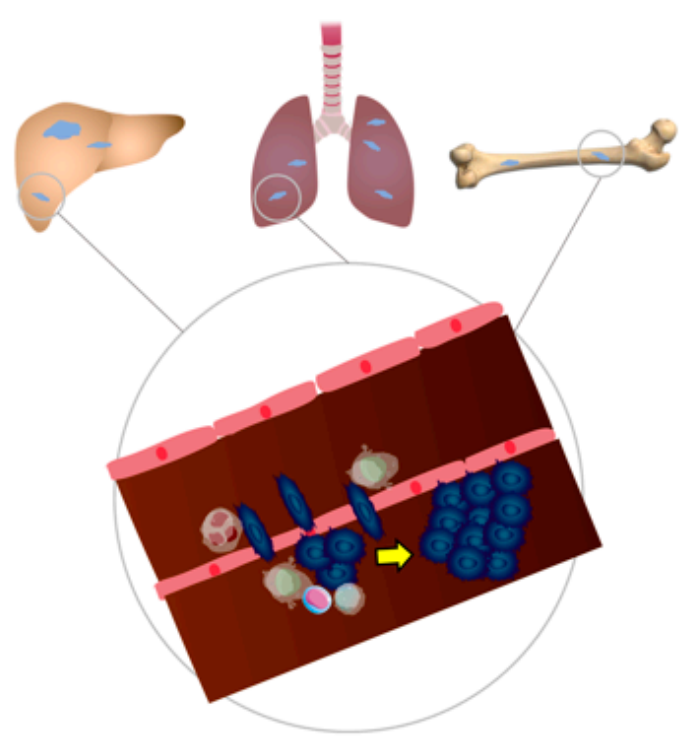

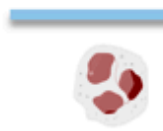

Neutrophil

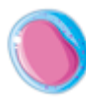

NK cell
CTCs survival in circulation

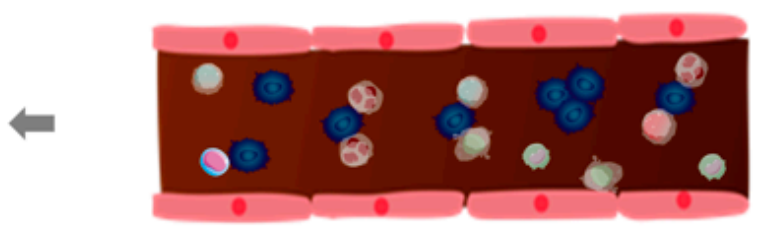

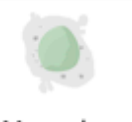

Macrophage

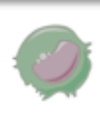

Monocyte

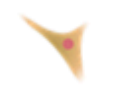

Fibroblast

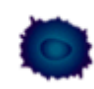

Tumor cell

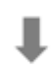

Figure 1. Metastasis Cascade: Interaction between CTCs and Immune Cells.

Metastasis consists of a series of steps including (1) local invasion of primary tumor cells into adjacent tissue; (2) intravasation (trans-endothelial migration into nearby blood vessels); (3) CTCs (transient traveling and survival in the circulatory system); (4) extravasation (CTCs travel out of the blood vessel and seed in bone marrow or other distant organs); (5) colonization (CTCs proliferate and grow at the distant sites, eventually becoming clinically detectable metastatic tumors). CTCs directly interact with immune cells in the circulation and finally escape from immune surveillance.

\subsection{Intravasation}

Intravasation is the process by which cancer cells shed from primary or metastatic deposits and traverse the endothelium to enter the bloodstream, thus, forming CTCs and pioneering the metastatic cascade. Immune cells that interact with CTCs during the initial stages of metastasis include neutrophils, natural killer (NK) cells, monocytes, macrophages, and T lymphocytes. 


\subsubsection{Neutrophils}

The recruitment of neutrophils by primary tumor is implicated in the elevated rate of intravasation in vivo [51]. In breast cancer patients, as well as in mouse models, neutrophils facilitate the intravasation of tumor cells by forming CTC-neutrophil clusters, which express higher levels of positive regulators of cell cycle and DNA replication programs than CTCs alone, leading to increased metastatic propensity and poor prognosis [22]. Activated neutrophils secrete neutrophil extracellular traps (NETs), which contain factors such as matrix-metalloprotein-9 (MMP-9), neutrophil elastase (NE), and cathepsin G (CG) that promote extracellular matrix (ECM) degradation and cellular aggregation. Evidently, these factors can promote CTC migration and invasion while enhancing proliferation and antiapoptosis traits of CTCs at the same time [52]. Accordingly, transcriptomic analysis on peripheral blood leukocytes from treatment-naïve renal cell carcinoma patients indicated that NET formation, as indicated by elevated expression of NET formation regulators, promotes CTC viability $[53,54]$. Another study also demonstrated that neutrophil activation in the blood correlates with CTC survival [54]. In early-stage breast cancer patients, increased levels of NETs in the blood have been proposed as a biomarker that specifically predict the chronic risk of liver metastases [53].

\subsubsection{NK Cells}

A study by Santos et al. demonstrated a close link between the number of CTCs and the cytotoxic activity of NK cells in the blood of breast, colorectal, and prostate cancer patients [55]. The NK cells from patients with a high number of CTCs showed diminished cytotoxicity, as compared to those isolated from patients with a low number of CTCs. This is consistent with an earlier study, where mice with low NK cell activity showed enhanced blood-borne tumor cell survival and increased incidence of metastasis [56,57].

\subsubsection{Monocytes and Macrophages}

Monocytes and macrophages have been reported to aid in intravasation via myriad mechanisms. A three-cell complex, termed "tumor microenvironment of metastasis doorway", composed of a perivascular macrophage, a tumor cell, and an endothelial cell, is found to act as a gateway for tumor cell hematogenous dissemination. Intravital highresolution microscopy revealed that perivascular macrophages promote transient vascular permeability by interacting with endothelial cells, via VEGFA signaling, and consequently facilitate the intravasation of tumor cells [58-60]. In addition, tumor- or CTC-educated macrophages influence almost all the steps of the metastatic cascade, such as accelerating invasion, intravasation, survival in the circulation, tumor cell arrest, extravasation, as well as durable growth at distant sites [61,62]. Solid tumor-based studies suggested that CTCs intravasate into the circulatory system along with TAMs [63,64]. Additional clinical evidence of the continued interaction of macrophages with tumor cells was found in the blood circulation of cancer patients. Despite the rarity of cell types, and the shear stresses within the vascular circulation, circulating CAMLs and macrophages with pro-angiogenic capacity have been found to migrate through the circulation, attached to CTCs in $10 \%$ of late-stage patients with breast, pancreatic, or prostate cancers [11]. Together, these lines of evidence demonstrated a critical role of macrophages in metastatic intravasation.

Besides immunosurveillance, macrophages are also involved in the establishment of the premetastatic niche, particularly in the lungs. Using an intravital two-photon lung imaging system, CTCs lodged in the capillaries of the lungs were found to shed microparticles into the vasculature, driven by high shear forces within seconds of arrival. Following CTC entry, myeloid cells, such as monocytes, macrophages, neutrophils and dendritic cells (DCs), ingest these large microparticles. Of note, tumor-ingesting macrophages display an activated phenotype and pro-metastatic function, while lung-resident conventional dendritic cells showed anti-metastasis effects [65]. These findings demonstrated the complex interplay between CTCs and various immune cells. 


\subsubsection{T Cells}

There are limited investigations into the role of $\mathrm{CD} 4^{+}$helper $\mathrm{T}$ cells and $\mathrm{CD} 8^{+}$cytotoxic $\mathrm{T}$ cells in the immune surveillance of CTCs. As such, receptor activator of nuclear kappa-B ligand (RANKL) expressed by tumor-infiltrating $\mathrm{CD}^{+} \mathrm{T}$ cells are thought to stimulate RANK, expressed on CTC from breast cancer, to enhanced intravasation [66,67]. In a more recent study, $\mathrm{CD} 4^{+} \mathrm{T}$ cells were found to be unexpectedly involved in vasculature and immune reprogramming, thereby contributing to impeding cancer cell intravasation [68]. In that study, $\mathrm{CD}^{+} \mathrm{T}$ cell deficiency resulted in reduced immune responses, lower expression of good-prognosis angiogenesis genes (GPAGs), and higher expression of poor-prognosis angiogenesis genes (PPAGs), defined by the author. Loss of $\mathrm{CD}^{+} \mathrm{T}$ cells also altered pathways and genes that regulate vessel normalization. Two studies have illustrated the safeguarding role of $\mathrm{CD} 8^{+} \mathrm{T}$ cells in intravasation. Increased CTCs were found in CD8 knockout mice with breast cancer, demonstrating that loss of cytotoxic $\mathrm{T}$ cells promoted CTCs survival, as well as increased intravasation [68,69]. However, the mechanisms by which interaction of CTCs and T lymphocytes contribute to intravasation have not been fully clarified. Therefore, understanding the role of different $\mathrm{T}$ cell subsets in different stages of metastasis cascade is necessary to validate the above findings.

\subsection{CTC Survival in Circulation}

Most CTCs undergo apoptosis, owing to physical stress, through shear and tear in the circulation and anoikis [70]. Further, immune cytotoxicity eliminates the majority of CTCs in the blood [71], and deprivation of growth and survival factors outside the tumor niche also contribute to CTC death [72]. Despite these harsh survival conditions, CTCs can survive in the blood and contribute to metastasis to secondary sites by mechanisms such as cellular mutation, cytokine and growth factor stimulation, and interactions with surrounding cell types [30,73]. Here, we focus on the vast interactions between CTCs and immune cells during their voyage from the blood to dormancy and colonization in secondary sites.

The small number of CTCs that survive are able to hijack immune cells and improve their survival odds. These resistant CTCs gain enhanced metastatic seeding capability by utilizing immune cells to amplify certain traits, such as migration ability and invasiveness, as well as to modify and adapt to unfavorable circumstances. Some of the major immune cell types that interact with CTCs in circulation include neutrophils, monocytes/macrophages, lymphocytes, and NK cells [30,74].

\subsubsection{Neutrophils}

CTC-neutrophil clusters are one of the common CTC clusters found in blood. As first responders, neutrophils are attracted to primary tumors and CTCs that produce granulocyte colony stimulating factor (G-CSF) and other neutrophil stimulating cytokines [22,75]. Initially, neutrophils induce inflammation and release hydrogen peroxide that are cytotoxic against CTCs [76]. However, as the cancer progresses, immunosuppressive TGF $\beta 1$ that originates from the primary tumor microenvironment, and platelets, can induce N2 neutrophil polarization, which aids in CTC survival and epithelial-mesenchymal transition (EMT) [77-79]. Additionally, CTCs can develop resistance towards neutrophil-mediated cell death, through mutation in the TLE1 gene that promotes NFkB-mediated cancer progression [80]. Neutrophils in CTC clusters are found to express adhesion factors, such as VCAM- 1 and intracellular adhesion molecule 1 receptor (ICAM-1), which likely explains how neutrophils form close "piggyback" adhesions with CTCs [81,82]. This close interaction between CTCs and neutrophil enhances the activation of proliferative pathways in CTCs via crosstalk of cytokines, such as IL-6 and IL-1 $\beta$, from neutrophils [75]. In addition to the pro-survival effects mentioned previously, NETs can serve as a protective cloak that bind to CTCs, via $\beta 1$-integrin, to protect them from shear stress and immune cytotoxicity in the blood [83]. 


\subsubsection{Monocytes and Macrophages}

Monocytes are another abundant circulating immune cell type found in CTC clusters. They patrol within the blood circulation, where they eliminate cellular debris and are a significant mediator of the inflammatory processes. Monocytes can present themselves with a diverse subset of phenotypes and functions, depending on the external stimuli in their immediate environment [84]. Shibuya et al. demonstrated that tissue repair promoting $\mathrm{Ym} 1^{+} \mathrm{Ly} 6 \mathrm{C}^{\text {hi }}$ monocytes promoted CTC-mediated lung metastasis in the presence of systemic inflammation [85], highlighting an important role for immunosuppressive monocytes in supporting CTC metastasis. Monocytes can mature into macrophages that acquire the ability to phagocytose larger targets, including CTCs. In fact, macrophages can detect and distinguish foreign cells from self-cells through CD47, a cell surface glycoprotein that serves as a "do not eat me" signal. Furthermore, CTCs and secondary metastases are found to express high levels of CD47, suggesting that they acquire better survival advantages in blood circulation and secondary growth sites, likely by evading immunogenic responses [86].

Aside from evading phagocytosis, CTCs also take advantage of macrophages in a direct manner, through cytokine crosstalk. Tumor cells release colony stimulating factor 1 (CSF1) that recruits macrophages and polarizes them towards tissue repair-promoting M2 TAMs, which, in turn, produce growth factors like epidermal growth factor (EGF) that further stimulates tumor cells to produce CSF-1, thus, forming a positive feedback loop $[87,88]$.

\subsubsection{T Cells}

Effector $\mathrm{CD}^{+}$and $\mathrm{CD} 8^{+} \mathrm{T}$ lymphocytes exert hostile responses toward CTCs in the circulation. Further, PD-L1 expression on T cells has been found to correlate with increased CTC survival in metastatic genitourinary cancer and advanced non-small cell lung cancer (NSCLC), along with lower $\mathrm{CD}^{+}$and $\mathrm{CD}^{+} \mathrm{T}$ cell numbers $[89,90]$. It is suggested that $\mathrm{PDL}^{+} \mathrm{CTC}$ are able to suppress $\mathrm{T}$ cell activation and, thereby, dampen the immune response against CTCs in the blood [91]. In another study, CTCs expressing elevated levels of T cell programmed cell death Fas ligand were detected in breast cancer patients, causing increased apoptosis of T cells in circulation [92]. These observations indicate that CTCs may depend on $\mathrm{T}$ cell deactivation and apoptosis to prolong their survival in circulation, as supported by their negative correlation with $\mathrm{CD}^{+}$and $\mathrm{CD} 8^{+} \mathrm{T}$ cell numbers and shorter overall patient survival [1].

Regulatory T cells (Tregs) are an immunosuppressive T lymphocyte subset that negatively regulate cytotoxic $\mathrm{T}$ lymphocyte activation [93]. The CTCs preferentially recruit circulating Tregs through the release of chemokines, such as CCL5, CCL22, CCL17, CXCL9 and CXCL10 [94]. Subsequently, circulating Tregs are activated by tumor-derived suppressive factors (TDSFs), including IL-10 and TGF $\beta 1$, to promote an immunosuppressive environment that limits $\mathrm{T}$ effector functions and contributes to CTC survival $[95,96]$. In addition, the RANKL, secreted by Tregs, can help promote tumor migration in RANK ${ }^{+}$ CTCs $[66,97]$. Evidently, CTC counts are positively correlated to circulating Tregs in various cancers, such as inflammatory breast cancer, hepatocellular carcinoma (HCC), and NSCLC $[1,98,99]$.

\subsubsection{NK Cells}

Similar to T lymphocytes, NK cells play a pivotal role in restricting CTC survival and metastasis through direct interception in circulation. The NK cells can initiate the indirect killing of CTCs through the secretion of the tumor necrosis factor-related apoptosisinducing ligand (TRAIL) that binds to apoptotic receptors on tumor cells $[100,101]$. Resistant CTCs are able to mitigate this by downregulating their death receptor 5 (DR5) expression on the cell surface [102]. The secretion of granzyme and perforin from NK cells represents another form of cytotoxicity towards CTCs that is deemed more effective, capable of eliminating up to $80 \%$ of CTCs and slowing down metastatic spread [103]. Low 
NK cell numbers are indicated to be an independent risk factor for CTCs and their progression [1]. In recent studies, CTC clusters were shown to evade NK cytotoxicity much more effectively than single CTCs [104]. Notably, NK cell-mediated cytotoxicity is suggested to be more potent towards CTCs with partial mesenchymal-like traits, though further insight is still required to comprehend the dynamic interaction between CTCs and NK cells from the blood to metastatic colonization [105].

\subsection{Extravasation and Colonization}

As CTCs roam in the bloodstream, a small percentage of these cells will get arrested in tight capillaries, which may be a prerequisite for extravasation [106]. The CTC clusters have better odds at initiating this process due to the large size that can get embedded in tight spaces for longer periods [107]. The cancer infiltration process can be promoted through several factors, including CTC expression of surface receptors and integrins for attachment, mechanical and physical pressure, chemotactic gradient from certain secondary sites, and with aid from immune cells in clusters [108]. Here, we focus on how immune cells support and mediate the extravasation and colonization of CTCs into secondary metastasis sites.

Upon arrest, leukocytes in CTC clusters interact with endothelial cells lining the vasculature that are essential for endothelial attachment. During this process, tumor cells secrete factors such as IL-8 to promote the leukocyte expression of adhesion receptors like $\beta 2$-integrin, that can bind directly to ICAM- 1 and E-selectin, present on endothelial cells [109]. For instance, tumor cells that are entrapped within NETs from neutrophils act as passengers, whereby neutrophils that express CD11a (LFA1) and CD11b (Mac-1) are able to interact with ICAM-1 on endothelial cells [110]. At the same time, tumor cells produce factors that upregulate these adhesion receptors and promote migration potential in neutrophils by delaying apoptosis [111]. Monocytes and TAMs, on the other hand, secrete cytokine and chemotactic factors, such as VEGF, TGF $\beta 1$, and CCL2, to increase vessel permeability and to destroy endothelial tight junctions, thereby mediating transendothelial migration $[112,113]$. Tumor cells are also capable of following the "microtracks" generated by macrophages, as they cross the endothelial border [114].

Tumor cells that infiltrated secondary sites, hereby termed disseminated tumor cells (DTCs), have to overcome immune surveillance at the secondary site and undergo mesenchymal-epithelial transition (MET) to gain the capacity to colonize upon the local niche. In this regard, immune surveillance at different organs poses different threats, depending on the local immune composition. In breast cancer/prostate cancer-mediated bone metastases, tumor cells actively modulate the local immune niche by secreting extracellular vesicles (EVs) and factors, including VEGF, IL-6, and IL-8, that promote osteoclast differentiation and activate osteoblasts to support osteoclast activities, which causes osteolysis. Subsequently, these activated bone cells also secrete tumor growth promoting factors like TGF $\beta 1$, to advocate tumor growth and, ultimately, form a positive feedback loop [115]. These interactions enable tumor cells to undergo "osteomimicry", where they express bone-related genes to adapt and expand upon bone sites [116]. T cells and NK cells play a prominent role in eliminating DTCs in metastatic niches [117]. In lung metastasis, tumors modify pre-metastatic niche by recruiting neutrophils to the lungs via immune-cancer crosstalk [118]. These neutrophils suppress T cell cytotoxicity via inducible nitric oxide synthase (iNOS) expression [119]. Furthermore, DTCs with altered antigen presentation characteristics are capable of minimizing $\mathrm{T}$ cell and NK cell cytotoxicity. In such cases, PD-L1 expression and downregulation of major histocompatibility complex I (MHC I) are modifications that allow tumors to evade NK and T cell-mediated killing, though NK cells may still recognize tumor cells with abnormally low MHC I levels [120,121]. Additionally, DTCs may recruit immunosuppressive myeloid cells to suppress NK cell activity [122]. For DTCs to fully integrate into the local niche, MET process is necessary for tumors to revert into epithelial forms. Moreover, TAMs secrete IL-35 that facilitates MET in tumor cells, through the activation of JAK2-STAT6-GATA3 signaling [123]. In the late stage of 
metastasis, DTCs that survive and have undergone EMT expand to form overt metastases upon acquiring sufficient growth signals in a favorable condition.

\section{Current Detection and Isolation Strategies for CTCs}

Despite steadfast advancement in CTC detection and enumeration technologies, several hurdles exist for current methodologies to accurately identify and discriminate CTCs, due to the presence of dynamic EMT phenotypes and other undiscovered CTC subtypes. Current detection strategies emphasize on discriminating CTCs, based on their biophysical characteristics and known biological markers. In the former, CTCs are physically distinguished based on their larger size and morphology, deformability, density, and electric charge [124]. Notable methods for this approach include Parsortix ${ }^{\mathrm{TM}}$, ScreenCell Cyto ${ }^{\circledR}$, ApoStream $^{\circledR}, \mathrm{CTCKey}^{\mathrm{TM}}$, and Accucyte [125-129]. A common ground for these techniques is that they excel in having a linearized and consistent workflow. Nonetheless, apparent drawbacks include low purity and inflexibility that are highly dependent on size and morphology of CTCs. In biological marker-based detection, CTCs are recognized by immunolabeling for the surface expression of known epithelial markers, such as EpCAM and CK $[130,131]$. CellSearch ${ }^{\circledR}$, MACS System, GEDI, GEM chip, flow cytometry, ImageStream ${ }^{\circledR}$, FASTcell, and Epic are several known detection systems that utilize this approach [132-139]. Although immunolabeling enables the accurate targeting of defined CTCs, certain CTCs are revealed to have minimal to no expression of conventional epithelial markers [140]. In addition, CTCs with partial to high EMT mesenchymal traits and unorthodox phenotypes, such as the newly recognized CHCs with both epithelial and leukocyte markers, may be excluded in these conventional platforms. In consideration of this, dynamic detection strategies are required to improve CTC identification and isolation outcomes. Accordingly, newfound approaches, such as AI-based machine learning identification of CTCs, offers versatile and robust strategies for image classification. Wang et al. utilized a convolutional neural network-based machine learning algorithm to identify and detect CTCs in microscopy images [141]. Future research endeavor requires the discovery of more CTC specific traits, as well as addressing the dynamic changes and complexity of CTC identification, with respect to single cells, clusters, hybrid EMT, and other unknown subtypes.

\section{Clinical Relevance of CTCs in Immunology}

\subsection{CTCs as a Therapeutic Target}

Although there is substantial evidence that the immune system plays a complex role in influencing the genesis, survival and successful seeding of CTCs, surprisingly little is available on the therapeutic targeting of CTC-immune cell interactions. Although there is ample evidence that successful chemo/radio/immunotherapeutic modalities, targeting the primary tumor, also promote the elimination of CTCs [142-145], the studies outlined below are those that aim specifically at CTCs as a target of therapy, summarized in Figure 2A.

An important avenue of CTC elimination involves their phagocytosis by macrophages. However, in most solid malignancies, macrophages often present with a tumor-promoting phenotype with impaired phagocytic functions (i.e., TAMs [146]). There have been a few approaches reported to promote macrophage-dependent elimination of tumor cells, primarily via monoclonal antibody therapies. Gul et al. reported that in a murine model of melanoma, during transit through the liver, CTCs are susceptible to phagocytosis by Kupffer cells (liver macrophages) $[147,148]$. They reported that CTC opsonization, following monoclonal antibody therapy, using antibodies against cancer-specific antigens stimulates Kupffer cells to eliminate melanoma CTCs, via antibody-dependent phagocytosis [147]. Their report of Kupffer-dependent CTC clearance is backed by a similar report from van der Bij et al., using a murine colorectal cancer model [149]. The "do not eat me" signal, CD47, has also been targeted via monoclonal antibodies (mAbs) to reverse CTC immune evasion. Lian et al. reported that the simultaneous blockage of PD-L1 and CD47 in a murine breast cancer model reduces metastasis more effectively compared to single therapy via CTC inhibition [150,151]. Although they did not mechanistically investigate the cause of CTC 
reduction, other groups have shown that $\mathrm{CD} 47$ blockage promotes macrophage-dependent phagocytosis $[152,153]$.

A

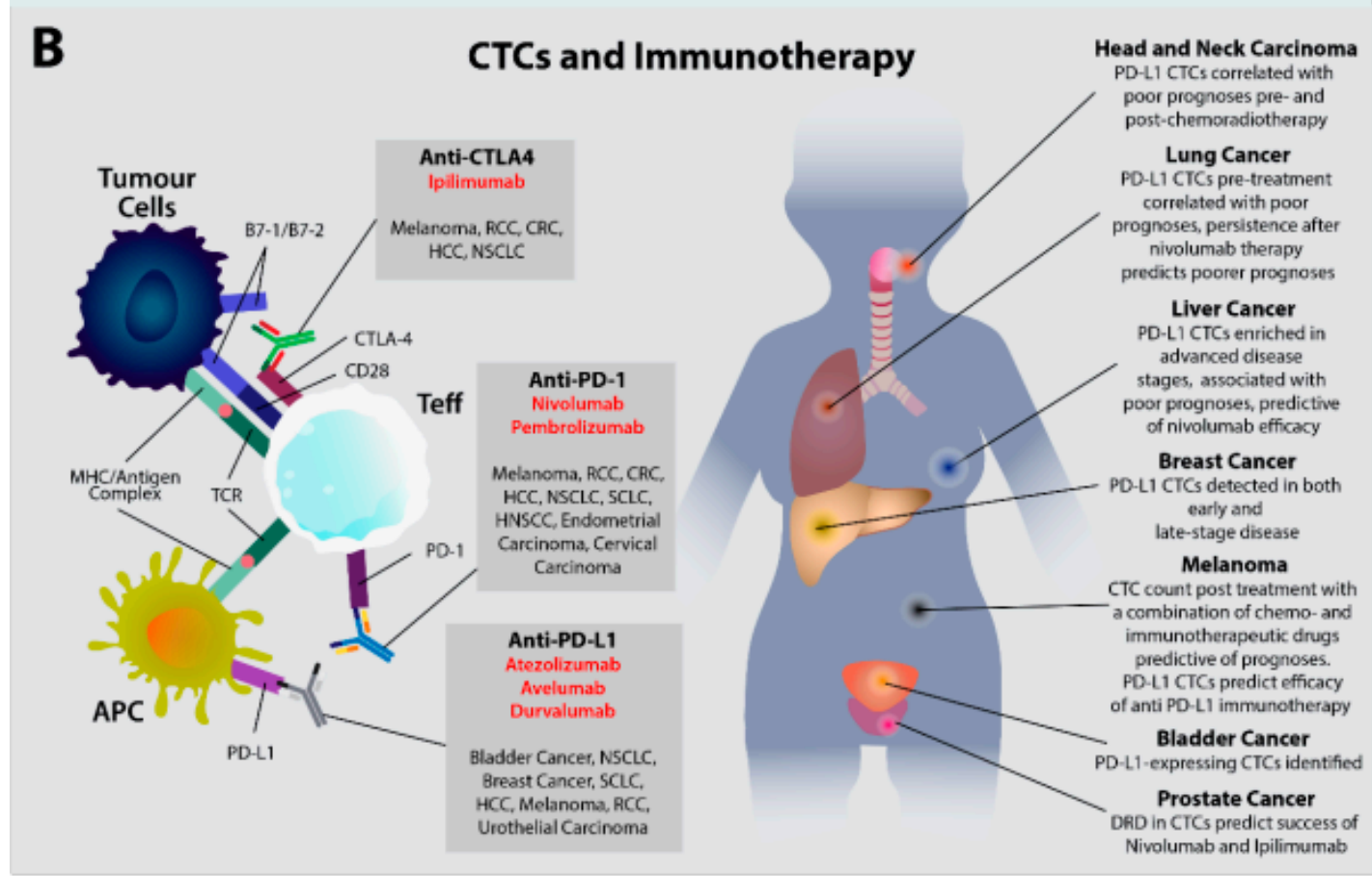

Therapies Targeting CTCs

Figure 2. Immunotherapy and CTCs. (A) Therapies targeting CTCs may rely on multiple strategies, including stimulating the phagocytic elimination of CTCs by macrophages through CD47 blocking. Elimination via CAR-T cells may be targeted by homing using an anti-EpCAM ScFv. These therapies may be given in combination with anti-PD-L1 therapy. TRAIL-mediated apoptosis of CTCs may be promoted by overexpressing TRAIL on platelets or by coating circulating leukocytes with TRAIL- 
containing liposomes. (B) ICIs have been widely used as therapeutic modalities for late-stage malignancies. Three classes of ICIs are currently in clinical use for different malignancies. The role of CTCs as biomarkers for ICI therapies are increasingly studied, with the greatest focus on the relevance of PD-L1 expression for prognostics and patient stratification. Abbreviations used: CTC = circulating tumor cell, SIRP $\alpha=$ signal regulatory protein alpha, TRAIL $=$ TNF-related apoptosis-inducing ligand, EpCAM = Epithelial cell adhesion molecule, $\mathrm{ScFv}=$ Single chain fragment variable, Teff = Effector T cells, CAR-T cell $=$ Chimeric antigen receptor $\mathrm{T}$ cell, $\mathrm{ICI}=$ immune checkpoint inhibitor, $\mathrm{RCC}=$ renal cell carcinoma, $\mathrm{CRC}=$ colorectal carcinoma, $\mathrm{HCC}=$ hepatocellular carcinoma, NSCLC = non-small cell lung carcinoma, SCLC = small cell lung carcinoma, HNSCC $=$ head and neck squamous cell carcinoma, $\mathrm{TCR}=\mathrm{T}$ cell receptor $\mathrm{MHC}=$ major histocompatibility complex, $\mathrm{PD}-1=$ programmed cell death protein1, PD-L1 = programmed death ligand 1, CTLA-4 = cytotoxic T-lymphocyte associated protein-4, CD = cluster of differentiation.

Another approach at CTC elimination utilizes the close association between CTCs and platelets during circulatory transit. Li et al. engineered platelets that overexpress membrane-bound TRAIL to promote CTC apoptosis [154]. They demonstrated that in murine models for breast and prostate cancers, recruitment of TRAIL-overexpressing platelet to CTC clusters (as part of the CTC "cloaking" strategy) resulted in reduced metastasis and CTC viability [154]. A more recent study by Ortiz-Otero et al., using TRAIL-overexpressing platelets, also reported similar results with primary-tumor-derived CTCs [155]. Another reported approach using TRAIL, involves generating TRAIL and E-selectin-containing liposomes [156]. These liposomes bind circulating leukocytes via their E-selectin (effectively coating these leukocytes with the accompanying TRAIL molecules with monocytes, neutrophils and NK-cells, showing the highest level of coating). These cells are then primed to promote TRAIL-mediated CTC apoptosis and were shown to successfully reduce lung metastasis in a murine colorectal cancer model [156]. Recent research has also suggested that EpCAM can be utilized as a target antigen for CAR-T cell therapy, potentially selectively eliminating CTCs. However, their reported efficacy seems to also be accompanied by an unfavorable toxicity profile [157].

Immunotherapeutic modalities are often prescribed as second or subsequent-line drugs, usually prescribed for late-stage disease, when CTCs are usually also at their peak abundance [158]. Overall, larger studies are required to derive stronger conclusions on the utility of CTCs to predict ICI efficacy and to refine patient stratification. For a more in-depth review of CTC in immunotherapeutics, Leone et al. and Schuster et al. also summarized the clinical evidence [2,6]. A list of more recent clinical trials can be viewed in Table 1 , updated to November 2021.

Table 1. Current clinical trials for CTCs in patients undergoing cancer immunotherapies. The list is based on the ClinicalTrials.gov database as of November 2021.

\begin{tabular}{|c|c|c|c|c|c|c|c|}
\hline Trial Number & Study Title & $\begin{array}{l}\text { Enrollment } \\
\quad \text { No. }\end{array}$ & Disease & Interventions & Status & $\begin{array}{l}\text { Start/Completion } \\
\text { Date }(\mathrm{m} / \mathrm{d} / \mathrm{y})\end{array}$ & Country \\
\hline NCT03986463 & $\begin{array}{l}\text { CIrculating Tumor } \\
\text { DNA in Lung } \\
\text { Cancer (CITaDeL): } \\
\text { Optimizing } \\
\text { Sensitivity and } \\
\text { Clinical Utility }\end{array}$ & 40 & $\begin{array}{l}\text { Lung } \\
\text { Neoplasms } \\
\text { NSCLC }\end{array}$ & ctDNA & Completed & $\begin{array}{l}5 / 1 / 2019- \\
12 / 31 / 2020\end{array}$ & $\begin{array}{c}\text { London } \\
\text { Regional } \\
\text { Cancer Program }\end{array}$ \\
\hline
\end{tabular}


Table 1. Cont.

\begin{tabular}{|c|c|c|c|c|c|c|c|}
\hline $\begin{array}{c}\text { Trial } \\
\text { Number }\end{array}$ & Study Title & $\begin{array}{l}\text { Enrollment } \\
\text { No. }\end{array}$ & Disease & Interventions & Status & $\begin{array}{l}\text { Start/Completion } \\
\text { Date }(\mathrm{m} / \mathrm{d} / \mathrm{y})\end{array}$ & Country \\
\hline NCT02827344 & $\begin{array}{c}\text { Feasibility Study } \\
\text { of PD-L1 } \\
\text { Expression } \\
\text { Analysis on } \\
\text { Circulating } \\
\text { Tumor Cells by } \\
\text { Immunocyto- } \\
\text { chemistry and } \\
\text { MDSCs Level } \\
\text { Evolution } \\
\text { Analysis in } \\
\text { NSCLC Treated } \\
\text { With PD- L1 or } \\
\text { PD1 Inhibitor }\end{array}$ & 200 & Lung Cancer & $\begin{array}{l}\text { Blood sample } \\
\text { collection for } \\
\text { CTCs and } \\
\text { MDSCs } \\
\text { analysis }\end{array}$ & Recruiting & $10 / 1 / 2015$ & $\begin{array}{l}\text { Larrey } \\
\text { Hospital } \\
\text { Toulouse, } \\
\text { France }\end{array}$ \\
\hline NCT03481101 & $\begin{array}{l}\text { WHENII-Early } \\
\text { Response } \\
\text { Evaluation With } \\
\text { FDG- PET/CT } \\
\text { and Liquid } \\
\text { Biopsy in Patients } \\
\text { with NSCLC }\end{array}$ & 60 & NSCLC & $\begin{array}{l}\text { PET/CT } \\
\text { CTCs } \\
\text { ct DNA }\end{array}$ & Recruiting & $2 / 28 / 2018$ & $\begin{array}{l}\text { University } \\
\text { Copenhagen }\end{array}$ \\
\hline NCT03926260 & $\begin{array}{l}\text { Early Assessment } \\
\text { of Response to } \\
\text { Treatment of } \\
\text { Metastatic Lung } \\
\text { Tumors Based on } \\
\text { Circulating } \\
\text { Tumor DNA }\end{array}$ & 100 & $\begin{array}{l}\text { Metastatic } \\
\text { NSCLC }\end{array}$ & $\begin{array}{l}\text { ctDNA } \\
\text { analysis }\end{array}$ & Recruiting & $6 / 27 / 2019$ & $\begin{array}{c}\text { Marie } \\
\text { MARCQ } \\
\text { La Roche-sur- } \\
\text { Yon, } \\
\text { France }\end{array}$ \\
\hline NCT04791215 & $\begin{array}{c}\text { Circulating } \\
\text { Tumor DNA } \\
\text { Alterations in } \\
\text { Non- small Cell } \\
\text { Lung Cancer } \\
\text { Patients Treated } \\
\text { with } \\
\text { Pembrolizumab }\end{array}$ & 37 & NSCLC & Observational & Recruiting & $2 / 1 / 2020$ & $\begin{array}{l}\text { Columbia } \\
\text { University, } \\
\text { United States }\end{array}$ \\
\hline NCT05091190 & $\begin{array}{l}\text { Immunotherapy } \\
\text { Clearance and } \\
\text { Phenotype of } \\
\text { Circulating } \\
\text { Tumor Cells in } \\
\text { Lung and Head } \\
\text { and Neck Cancers }\end{array}$ & 60 & $\begin{array}{c}\text { Metastatic } \\
\text { NSCLC } \\
\text { Metastatic } \\
\text { Head and } \\
\text { Neck Cancer }\end{array}$ & Blood draws & $\begin{array}{l}\text { Not yet } \\
\text { recruiting }\end{array}$ & October 2021 & $\begin{array}{c}\text { Croix Rousse } \\
\text { Hospital, } \\
\text { France }\end{array}$ \\
\hline NCT04053725 & $\begin{array}{l}\text { A Prospective } \\
\text { Study of Blood } \\
\text { Circulating } \\
\text { Tumor DNA for } \\
\text { the Prediction of } \\
\text { Efficacy in } \\
\text { Immunotherapy } \\
\text { for Advanced } \\
\text { Gastric Cancer. }\end{array}$ & 200 & $\begin{array}{c}\text { Stomach } \\
\text { Neoplasms }\end{array}$ & NP & Unknown & $2 / 1 / 2019$ & $\begin{array}{c}\text { Cancer center } \\
\text { of Sun Yat-sen } \\
\text { University, } \\
\text { China }\end{array}$ \\
\hline
\end{tabular}


Table 1. Cont.

\begin{tabular}{|c|c|c|c|c|c|c|c|}
\hline $\begin{array}{c}\text { Trial } \\
\text { Number }\end{array}$ & Study Title & $\begin{array}{l}\text { Enrollment } \\
\text { No. }\end{array}$ & Disease & Interventions & Status & $\begin{array}{l}\text { Start/Completion } \\
\text { Date }(\mathrm{m} / \mathrm{d} / \mathrm{y})\end{array}$ & Country \\
\hline NCT04944173 & $\begin{array}{c}\text { A Study of } \\
\text { Durvalumab and } \\
\text { Stereotactic } \\
\text { Radiotherapy for } \\
\text { Stage I Non-Small } \\
\text { Cell Lung Cancer } \\
\text { (SCION) }\end{array}$ & 94 & $\begin{array}{l}\text { NSCLC } \\
\text { Lung Cancer, } \\
\text { Stage I } \\
\text { Lung Adeno- } \\
\text { carcinoma, } \\
\text { Stage I } \\
\text { Lung } \\
\text { Squamous } \\
\text { Cell } \\
\text { Carcinoma } \\
\text { Stage I }\end{array}$ & $\begin{array}{l}\text { Durvalumab } \\
\text { Stereotactic } \\
\text { Body Radio- } \\
\text { therapy } \\
\text { ct DNA assay }\end{array}$ & $\begin{array}{l}\text { Phase } 2 \\
\text { Not yet } \\
\text { recruiting }\end{array}$ & June 2021 & $\begin{array}{c}\text { BC Cancer- } \\
\text { Kelowna, } \\
\text { Canada }\end{array}$ \\
\hline NCT04966663 & $\begin{array}{c}\text { From Liquid } \\
\text { Biopsy to Cure: } \\
\text { Using ctDNA } \\
\text { Detection of } \\
\text { Minimal Residual } \\
\text { Disease to } \\
\text { Identify Patients } \\
\text { for Curative } \\
\text { Therapy After } \\
\text { Lung Cancer } \\
\text { Resection }\end{array}$ & 66 & NSCLC & $\begin{array}{l}\text { Nivolumab } \\
\text { Pemetrexed } \\
\text { Gemcitabine } \\
\text { Cisplatin } \\
\text { Carboplatin } \\
\text { ctDNA blood } \\
\text { test }\end{array}$ & $\begin{array}{l}\text { Phase } 2 \\
\text { Not yet } \\
\text { recruiting }\end{array}$ & $11 / 1 / 2021$ & $\begin{array}{c}\text { Princess } \\
\text { Margaret } \\
\text { Cancer Centre, } \\
\text { Canada }\end{array}$ \\
\hline NCT04993014 & $\begin{array}{c}\text { Circulating } \\
\text { Tumor Cells and } \\
\text { Treatment } \\
\text { De-escalation } \\
\text { After } \\
\text { Neoadjuvant } \\
\text { Therapy for HER2 } \\
\text { Positive Breast } \\
\text { Cancer }\end{array}$ & 80 & $\begin{array}{c}\text { Breast } \\
\text { Neoplasms } \\
\text { HER2+ Breast } \\
\text { Cancer }\end{array}$ & $\begin{array}{c}\text { Pertuzumab } \\
\text { Trastuzumab } \\
\text { CTCs }\end{array}$ & $\begin{array}{l}\text { Phase } 2 \\
\text { Recruiting }\end{array}$ & $3 / 1 / 2021$ & $\begin{array}{c}\text { A.C. Camargo } \\
\text { Cancer Center, } \\
\text { Brazil }\end{array}$ \\
\hline NCT04168931 & $\begin{array}{c}\text { Efficacy of } \\
\text { Adding } \\
\text { Trastuzumab to } \\
\text { Standard } \\
\text { Chemotherapy in } \\
\text { Patients with } \\
\text { Advanced } \\
\text { HER2-negative } \\
\text { Gastric Cancer } \\
\text { and HER2 } \\
\text { Positive } \\
\text { Expression in } \\
\text { Circulating } \\
\text { Tumor Cells }\end{array}$ & 85 & $\begin{array}{l}\text { Gastric Cancer } \\
\text { Stage IV }\end{array}$ & Trastuzumab & $\begin{array}{l}\text { Phase } 2 \\
\text { Recruiting }\end{array}$ & $1 / 1 / 2020$ & $\begin{array}{c}\text { AC Camargo } \\
\text { Cancer Center, } \\
\text { Brazil }\end{array}$ \\
\hline
\end{tabular}


Table 1. Cont.

\begin{tabular}{|c|c|c|c|c|c|c|c|}
\hline $\begin{array}{l}\text { Trial } \\
\text { Number }\end{array}$ & Study Title & $\begin{array}{l}\text { Enrollment } \\
\text { No. }\end{array}$ & Disease & Interventions & Status & $\begin{array}{l}\text { Start/Completion } \\
\text { Date }(\mathrm{m} / \mathrm{d} / \mathrm{y})\end{array}$ & Country \\
\hline NCT04367311 & $\begin{array}{c}\text { Adjuvant } \\
\text { Treatment with } \\
\text { Cisplatin-based } \\
\text { Chemotherapy } \\
\text { Plus Concomitant } \\
\text { Atezolizumab in } \\
\text { Patients with } \\
\text { Stage I } \\
\text { (Tumors } \geq 4 \mathrm{~cm} \text { ), } \\
\text { IIA, IIB, and } \\
\text { Select IIIA } \\
\text { [T3N1-2, T4N0-2] } \\
\text { Resected NSCLC } \\
\text { and the Clearance } \\
\text { of ctDNA }\end{array}$ & 100 & NSCLC & $\begin{array}{l}\text { Atezolizumab } \\
\text { Docetaxel } \\
\text { Cisplatin } \\
\text { Pemetrexed }\end{array}$ & $\begin{array}{l}\text { Phase } 2 \\
\text { Recruiting }\end{array}$ & $5 / 22 / 2020$ & $\begin{array}{c}\text { Northwestern } \\
\text { University, } \\
\text { United States }\end{array}$ \\
\hline
\end{tabular}

\subsection{CTCs as Diagnostic and Therapeutic Biomarkers}

In contrast to the scarcity of evidence found for CTC-targeted therapies, a much more well-researched area of CTC biology concerns their utility as biomarkers (a representative surrogate for primary and metastatic tumors, used as clinical guides for patient stratification, prognostic determination, or therapeutic evaluation [159]). Often grouped together with circulating tumor DNA (ctDNA), as cancer-specific biomarkers obtained from the blood, liquid biopsies are much easier and less invasive to obtain compared to tumor biopsies [160]. The value of CTC liquid biopsies in cancer prognostics has been well documented for many solid tumors in the clinical setting, summarized in Figure 3. The $\mathrm{EpCAM}^{+}$CTC-based CellSearch test is currently the only FDA-approved clinical platform for use in prognostics and patient stratification in metastatic breast, prostate and colorectal cancer [131]; however, this have also have been used to research other malignancies [161].

Although primarily associated with metastasis and late-stage malignancies, CTCs have also been demonstrated to be present in the early stages of many cancers [162], as even stage I epithelial tumors have been shown to release CTCs [163,164]. This has driven research into the utility of CTCs as a highly specific early diagnostic tool. In patients with risk factors to the development of malignancies, CTCs may be released in small quantities by tumors which are not macroscopically detectable [165]. This approach allows for these clinically asymptomatic tumors to be detected early. Its role in screening has been demonstrated for early detection of lung cancer in patients with COPD [166], as well as for early or asymptomatic HCC [167], prostate cancer and breast cancer [168].

With the use of scRNA-seq becoming increasingly common, deeper investigations into the transcriptomic diversity of CTCs have been some of the more recent highlights in the field. Using metastatic HCC samples, D'avola et al. used scRNA-seq to identify distinct expression profiles in different HCC CTC populations, showing that some CTCs show upregulation of angiogenesis-related genes, and in others, KRAS and G2M checkpoint genes [169]. In metastatic breast cancer, De Luca et al. showed that not only do CTCs exhibit significant interpatient heterogeneity, single CTCs may possess unique mutations which will be lost in bulk analysis [170]. In the same paper, they also reported that the mutational landscape of CTCs may be completely altered following treatment [170]. A recent publication by Sun et al. described a high degree of spatial heterogeneity of the CTC transcriptional landscape in HCC via scRNA-seq [96]. They identified a large number of transcriptomic differences between CTCs drawn from liver efferent (representing primary tumor heterogeneity) and efferent (representing CTC adaptation in circulation) vessels. 
They also identified CCL5 as being increasingly upregulated, the longer CTCs circulate as an immune evasion mechanism, by recruiting Tregs in circulation [96]. Single-cell analysis also allows for better discrimination of CTC subpopulations, classifying them based on their transcriptional signatures or drug resistance. For example, in metastatic pancreatic cancer, Ting et al. was able to segregate CTCs into three transcriptionally distinct groups (classical CTCs, platelet-adherent CTCs and a subset, exhibiting high proliferation [171]). Aberrant signaling pathways in small populations of CTCs may also contribute to partial drug resistance. Miyamoto et al. reported that increased noncanonical Wnt signaling, in a population of pancreatic cancer CTCs, allowed their survival against antiandrogenic agents, which potentially allows for relapse or treatment failure [172].
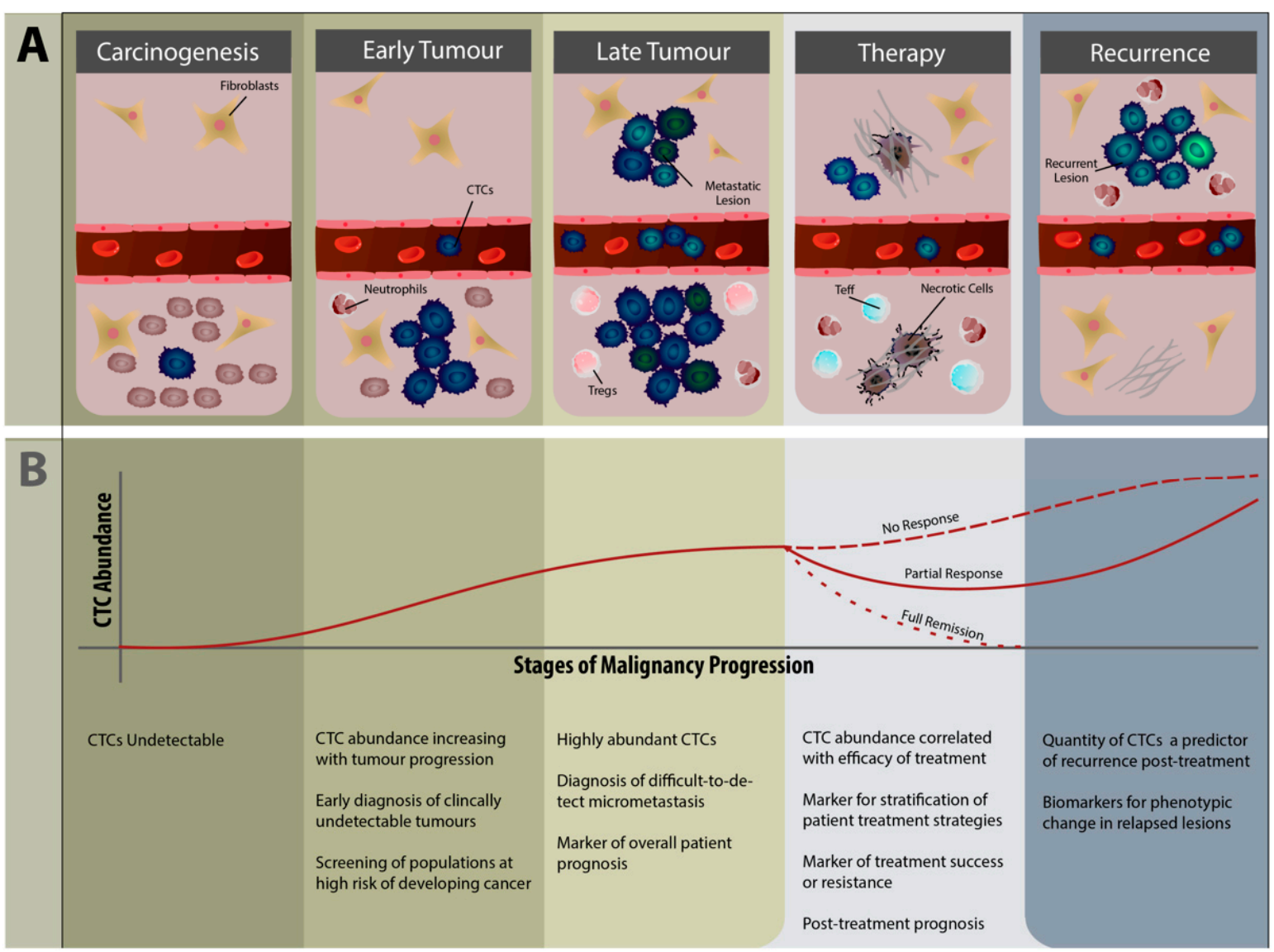

Figure 3. The Role of Circulating Tumor Cells in the Clinical Setting. (A) CTCs are released during the progression of tumor growth, being detectable even during the early stages of malignancies. At later stages, CTCs show higher heterogeneity and may reflect the mutational profiles of the primary tumor or metastatic lesions. The heterogeneity of CTCs may also aid with the survival of smaller resistant populations during treatment, which then promotes disease recurrence. (B) Once CTCs are released into the circulation during the early stages of malignancies, they may be useful as early diagnostic markers. As abundance increases during later disease stages, more detailed phenotypic assessments may inform of potential tropism to certain organs for metastasis as well as long-term patient prognoses. Prior to and during treatment, stratification strategies, treatment efficacy and post-treatment prognosis may be informed via CTC analysis with CTC abundance typically being inversely correlated with treatment success. Finally, likelihood of tumor recurrence may also be predicted via CTC analysis. Abbreviations used: CTC = circulating tumor cell, Treg = regulatory T cells, Teff $=$ Effector $\mathrm{T}$ cells.

A more recent development in the field is research into the predictive and evaluative value of CTCs in immunotherapeutic regimens (Figure 2B). The CTCs hold substantial 
promise as immunotherapeutic biomarkers due to their progressive enrichment during disease progression. Immunotherapeutic modalities are often administered as second or subsequent-line drugs, usually prescribed for late-stage disease, when CTCs are at their peak abundance [158]. As mentioned previously, PD-L1 has been discovered on CTCs, and this has driven interest in their role during immune checkpoint inhibitor (ICI) therapy. Although most of the research in the field have been focused on ICI therapies, some recent work on their utility in adoptive cell transfer and DC immunotherapy will also be highlighted.

Immune checkpoint inhibitor therapy has been the most successful immunotherapeutic modality to date, with anti-CTLA-4 and anti-PD-1/PD-L1 mAbs already in clinical use [173]. Additionally, CTC quantification and qualitative analysis in patients receiving ICIs suggests that their analysis pre- and post-treatment may be prognostically useful in predicting overall survival and treatment response. In malignant melanoma, two separate groups used a combination of chemotherapeutic and ICI agents to investigate the prognostic utility of CTCs and concluded that changes to CTC counts post-treatment is a good marker of prognosis $[174,175]$. More detailed qualitative analysis of melanoma CTCs showed that the presence of PD-L1 ${ }^{+}$CTCs pre-treatment predicts sensitivity to anti-PD-1 ICIs [176,177]. Conversely, expression of Catenin Beta 1 on CTCs is a predictor of resistance to ICI therapy [178]. More in-depth analysis of melanoma CTCs using RNA signatures have also been recently reported [179].

In lung cancer, the presence of PD-L1 on NSCLC CTCs was reported as a predictor of lower overall survival (OS) [180], although a different group did not find a statistically significant result [181]. Another group reported poorer prognoses of patients with PD-L1 ${ }^{+}$ CTCs and that persistence of PD-L1 ${ }^{+}$CTCs after nivolumab therapy is associated with worse overall survival [182]. Further studies by Guibert et al. and Dhar et al. showed that higher PD-L1 ${ }^{+}$CTC count pre-treatment is associated with worse progression-free survival (PFS) and that CTCs express higher levels of PD-L1 compared to primary tumors $[183,184]$. Although ICIs have not been extensively studied for breast carcinomas, Mazel et al. demonstrated the presence of PD-L1 on $68 \%$ of breast cancer CTCs [185]. Expanding on this, Schott et al. found that PD-L1 positive CTCs are present on both earlier and metastatic disease stages [186] and reported that one patient showed a reduction in PD-L1+ CTCs, with successful nivolumab and ipilimumab treatment.

Other malignancies with CTCs being studied as biomarkers for immunotherapy include prostate, bladder [187], head and neck squamous cell carcinoma (HNSCC) and HCC. In metastatic prostate cancer, with CTCs expressing AR-V7, Boudadi et al. reported that nivolumab and ipilimumab are efficacious only when tumors also show DNA-repair deficiencies [188]. In HNSCC, the presence of PD-L1 ${ }^{+}$CTCs in HNSCC pre-treatment was associated with poorer prognoses [181] and lower PFS and OS post-chemoradiotherapy [189]. In HCC, the presence of PD-L1 ${ }^{+}$CTCs is a predictor of worse OS but predicts a positive response to nivolumab treatment [190].

Studies addressing the role of CTCs in DC vaccination and ACT therapies are much less prevalent than for ICIs, with only the DC vaccine Sipuleucel-T in clinical use for prostate cancer [191]. Rekoske et al. found that PD-L1 expression on CTCs increased after administration of Sipuleucel-T and is associated with sustained T-cell responses and longer PFS [192]. In autogeneic NK-cell adoptive cell transfer for breast cancer and NSCLC, CTC quantity is negatively correlated with therapeutic efficacy $[193,194]$.

Although momentum has been growing in efforts to bring relevance to CTCs, as both targets and biomarkers of cancer therapy, much work remains. Most studies targeting CTCs via immunotherapies are still at the preclinical stage and clinical biomarker studies often involve small study populations. Deeper investigations are still required to fully translate the mechanistic findings of CTC immunology onto the bedside. 


\subsection{Future Avenues of CTC Research}

Efforts to understand CTC complexity have recently been supported by the increasing accessibility of single-cell transcriptomic analysis. In addition to the high spatiotemporal heterogeneity seen in primary lesions, CTCs may undergo various degrees of EMT, resulting in an even more varied transcriptome [10]. Further, CTC clusters have been shown to be composed of CTCs at different stages of EMT, where individual CTCs possess specialized roles in causing successful metastasis $[10,195]$. Appreciating the diversity of CTCs may illuminate more complex immune-CTC interactions, although research on the topic is very limited at the time of writing. Notably, Sun et al. demonstrated the spatial heterogeneity of CTCs by investigating transcriptomic differences between HCC CTCs drawn from liver efferent and afferent vessels (reflecting newly-released and circulation-adapted CTCs, respectively [96]). They identified CCL5 production as a CTC immune evasion strategy by recruiting Tregs in circulation, with levels of CCL5 increasing, the longer CTCs are in circulation [96]. Single-cell analyses also allow for better discrimination of CTC subpopulations, classifying them based on their transcriptional signatures [171] or drug resistance [172]. Identifying the immunological significance of these subpopulations may be an interesting avenue of research.

With the recent advent of personalized neoantigen cancer vaccines [196], CTCs may find utility for neoantigen screening. Neoantigen vaccines have been shown to be successful modalities for multiple cancer types, with very favorable toxicity profiles, due to their high specificity [197-199]. Although these studies relied on the sequencing of primary tumor biopsies, performing neoantigen screening via liquid biopsies may become increasingly feasible. A recent study in NSCLC, by Jia et al., showed that neoantigens identified from primary tumor biopsies were also detectable on ctDNAs. They then tracked the success of ICI therapy via fluctuations in neoantigen ctDNA abundance [200]. This suggests that neoantigen sequences can be tracked from liquid biopsies. However, as of the time of writing, there are still no reports on neoantigen detection using CTCs. A large caveat to this approach, however, is that there may be varying levels of similarity between the transcriptomic profile seen in CTCs and primary or metastatic lesions $[10,201,202]$. As such, extrapolating any neoantigen findings in CTCs to primary or metastatic lesions requires much scrutiny to establish their clinical significance.

Another field that is rapidly developing is the use of machine learning methods for CTC analysis, which provides a fully automated and robust platform for CTC enumeration. These methods can identify and characterize CTCs in heterogeneous liquid biopsies in a reproducible and accurate manner $[203,204]$. The CTC counts were obtained by combining autoencoding convolutional neural networks $(\mathrm{CNN})$ with advanced visualization techniques to predict overall survival in metastatic breast cancer patients [205]. The CNN have also been employed to detect and classify rare CTC cells from metastatic renal cell carcinoma patients [141]. Likewise, deep learning radiomics was employed for CTC counts to predict disease recurrence in early-stage non-small cell lung cancer patients, treated with stereotactic body radiation therapy [206].

\section{Conclusions}

Multiple studies have established the important role of CTCs during the metastasis process. CTCs interact with major immune cells, including neutrophils, monocytes, platelets, T cells and NK cells, to survive in circulation, evade destruction, proliferate, and finally colonize secondary sites. The CTCs interact with immune cells via cytokines and chemotactic factors. Although single CTCs are easily destroyed in circulation, cluster formation of CTCs with immune cells has allowed for more resistant CTCs, with enhanced migratory and invasive abilities that promote metastatic seeding. Various studies have provided valuable insights into the role of CTCs during metastasis. However, a number of questions still remain unanswered. For example, the dynamic interaction between CTCs and NK cells from circulation to metastatic colonization and the role of different $\mathrm{T}$ cell subsets in different stages of metastasis cascade. Key future research directions include 
understanding CTC heterogeneity, the use of immunotherapy to target CTCs, and the utility of CTCs in neoantigen screening. A major hurdle in CTC research is the rarity and fragility of these cells in liquid biopsies. With the advent of scRNA sequencing techniques, allowing for analysis at single cell level, these limitations can be overcome.

Author Contributions: Formal analysis, E.D., K.H.L., M.W., K.J.W.; investigation, E.D., K.H.L., M.W., K.J.W.; writing—original draft preparation, E.D., K.H.L., M.W., K.J.W., K.T.C.; writing-review and editing, E.D., K.H.L., M.W., K.J.W., K.T.C.; visualization, E.D., K.H.L., M.W., K.J.W.; supervision, K.T.C.; project administration, K.T.C.; funding acquisition, K.T.C. All authors have read and agreed to the published version of the manuscript.

Funding: This work was funded by Croucher Foundation grant number 9509002.

Institutional Review Board Statement: Not applicable.

Informed Consent Statement: Not applicable.

Data Availability Statement: Not applicable.

Conflicts of Interest: The authors declare no conflict of interest.

\section{References}

1. Ye, L.; Zhang, F.; Li, H.; Yang, L.; Lv, T.; Gu, W.; Song, Y. Circulating Tumor Cells Were Associated with the Number of T Lymphocyte Subsets and NK Cells in Peripheral Blood in Advanced Non-Small-Cell Lung Cancer. Dis. Markers 2017, 2017, 5727815. [CrossRef] [PubMed]

2. Schuster, E.; Taftaf, R.; Reduzzi, C.; Albert, M.K.; Romero-Calvo, I.; Liu, H. Better together: Circulating tumor cell clustering in metastatic cancer. Trends Cancer 2021, 7, 1020-1032. [CrossRef] [PubMed]

3. Pimienta, M.; Edderkaoui, M.; Wang, R.; Pandol, S. The potential for circulating tumor cells in pancreatic cancer management. Front. Physiol. 2017, 8, 381. [CrossRef] [PubMed]

4. Agashe, R.; Kurzrock, R. Circulating Tumor Cells: From the Laboratory to the Cancer Clinic. Cancers 2020, 12, 2361. [CrossRef]

5. Amintas, S.; Bedel, A.; Moreau-Gaudry, F.; Boutin, J.; Buscail, L.; Merlio, J.-P.; Vendrely, V.; Dabernat, S.; Buscail, E. Circulating Tumor Cell Clusters: United We Stand Divided We Fall. Int. J. Mol. Sci. 2020, 21, 2653. [CrossRef]

6. Leone, K.; Poggiana, C.; Zamarchi, R. The Interplay between Circulating Tumor Cells and the Immune System: From Immune Escape to Cancer Immunotherapy. Diagnostics 2018, 8, 59. [CrossRef]

7. Zhang, T.; Agarwal, A.; Almquist, R.G.; Runyambo, D.; Park, S.; Bronson, E.; Boominathan, R.; Rao, C.; Anand, M.; Oyekunle, T.; et al. Expression of immune checkpoints on circulating tumor cells in men with metastatic prostate cancer. Biomark. Res. 2021, 9, 14. [CrossRef]

8. Bergmann, S.; Coym, A.; Ott, L.; Soave, A.; Rink, M.; Janning, M.; Stoupiec, M.; Coith, C.; Peine, S.; von Amsberg, G.; et al. Evaluation of PD-L1 expression on circulating tumor cells (CTCs) in patients with advanced urothelial carcinoma (UC). Oncoimmunology 2020, 9, 1738798. [CrossRef]

9. Ashworth, T. A case of cancer in which cells similar to those in the tumours were seen in the blood after death. Aust. Med. J. 1869, 14, 146.

10. Keller, L.; Pantel, K. Unravelling tumour heterogeneity by single-cell profiling of circulating tumour cells. Nat. Rev. Cancer 2019, 19, 553-567. [CrossRef]

11. Adams, D.L.; Martin, S.S.; Alpaugh, R.K.; Charpentier, M.; Tsai, S.; Bergan, R.C.; Ogden, I.M.; Catalona, W.; Chumsri, S.; Tang, C.-M. Circulating giant macrophages as a potential biomarker of solid tumors. Proc. Natl. Acad. Sci. USA 2014, 111, 3514-3519. [CrossRef] [PubMed]

12. Dietz, M.S.; Sutton, T.L.; Walker, B.S.; Gast, C.E.; Zarour, L.; Sengupta, S.K.; Swain, J.R.; Eng, J.; Parappilly, M.; Limbach, K.; et al. Relevance of circulating hybrid cells as a non-invasive biomarker for myriad solid tumors. Sci. Rep. 2021, 11, 13630. [CrossRef] [PubMed]

13. Sun, Y.F.; Xu, Y.; Yang, X.R.; Guo, W.; Zhang, X.; Qiu, S.J.; Shi, R.Y.; Hu, B.; Zhou, J.; Fan, J. Circulating stem cell-like epithelial cell adhesion molecule-positive tumor cells indicate poor prognosis of hepatocellular carcinoma after curative resection. Hepatology 2013, 57, 1458-1468. [CrossRef] [PubMed]

14. Witzig, T.E.; Bossy, B.; Kimlinger, T.; Roche, P.C.; Ingle, J.N.; Grant, C.; Donohue, J.; Suman, V.J.; Harrington, D.; Torre-Bueno, J.; et al. Detection of circulating cytokeratin-positive cells in the blood of breast cancer patients using immunomagnetic enrichment and digital microscopy. Clin. Cancer Res. 2002, 8, 1085-1091.

15. Gold, B.; Cankovic, M.; Furtado, L.V.; Meier, F.; Gocke, C.D. Do Circulating Tumor Cells, Exosomes, and Circulating Tumor Nucleic Acids Have Clinical Utility?: A Report of the Association for Molecular Pathology. J. Mol. Diagn. 2015, 17, 209-224. [CrossRef]

16. Meng, S.; Tripathy, D.; Frenkel, E.P.; Shete, S.; Naftalis, E.Z.; Huth, J.F.; Beitsch, P.D.; Leitch, M.; Hoover, S.; Euhus, D. Circulating tumor cells in patients with breast cancer dormancy. Clin. Cancer Res. 2004, 10, 8152-8162. [CrossRef] 
17. Rossi, E.; Basso, U.; Celadin, R.; Zilio, F.; Pucciarelli, S.; Aieta, M.; Barile, C.; Sava, T.; Bonciarelli, G.; Tumolo, S. M30 neoepitope expression in epithelial cancer: Quantification of apoptosis in circulating tumor cells by CellSearch analysis. Clin. Cancer Res. 2010, 16, 5233-5243. [CrossRef]

18. Luo, Q.; Wang, C.; Peng, B.; Pu, X.; Cai, L.; Liao, H.; Chen, K.; Zhang, C.; Cheng, Y.; Pan, M. Circulating Tumor-Cell-Associated White Blood Cell Clusters in Peripheral Blood Indicate Poor Prognosis in Patients With Hepatocellular Carcinoma. Front. Oncol. 2020, 10. [CrossRef]

19. Yu, M.; Bardia, A.; Wittner, B.S.; Stott, S.L.; Smas, M.E.; Ting, D.T.; Isakoff, S.J.; Ciciliano, J.C.; Wells, M.N.; Shah, A.M. Circulating breast tumor cells exhibit dynamic changes in epithelial and mesenchymal composition. Science 2013, 339, 580-584. [CrossRef]

20. Cristofanilli, M.; Budd, G.T.; Ellis, M.J.; Stopeck, A.; Matera, J.; Miller, M.C.; Reuben, J.M.; Doyle, G.V.; Allard, W.J.; Terstappen, L.W. Circulating tumor cells, disease progression, and survival in metastatic breast cancer. N. Engl. J. Med. 2004, 351, 781-791. [CrossRef]

21. Aceto, N.; Bardia, A.; Miyamoto, D.T.; Donaldson, M.C.; Wittner, B.S.; Spencer, J.A.; Yu, M.; Pely, A.; Engstrom, A.; Zhu, H.; et al Circulating tumor cell clusters are oligoclonal precursors of breast cancer metastasis. Cell 2014, 158, 1110-1122. [CrossRef] [PubMed]

22. Szczerba, B.M.; Castro-Giner, F.; Vetter, M.; Krol, I.; Gkountela, S.; Landin, J.; Scheidmann, M.C.; Donato, C.; Scherrer, R.; Singer J.; et al. Neutrophils escort circulating tumour cells to enable cell cycle progression. Nature 2019, 566, 553-557. [CrossRef] [PubMed]

23. Hou, J.-M.; Krebs, M.G.; Lancashire, L.; Sloane, R.; Backen, A.; Swain, R.K.; Priest, L.; Greystoke, A.; Zhou, C.; Morris, K. Clinical significance and molecular characteristics of circulating tumor cells and circulating tumor microemboli in patients with small-cell lung cancer. J. Clin. Oncol. 2012, 30, 525-532. [CrossRef] [PubMed]

24. Giuliano, M.; Shaikh, A.; Lo, H.C.; Arpino, G.; De Placido, S.; Zhang, X.H.; Cristofanilli, M.; Schiff, R.; Trivedi, M.V. Perspective on circulating tumor cell clusters: Why it takes a village to metastasize. Cancer Res. 2018, 78, 845-852. [CrossRef] [PubMed]

25. Hou, H.W.; Warkiani, M.E.; Khoo, B.L.; Li, Z.R.; Soo, R.A.; Tan, D.S.-W.; Lim, W.-T.; Han, J.; Bhagat, A.A.S.; Lim, C.T. Isolation and retrieval of circulating tumor cells using centrifugal forces. Sci. Rep. 2013, 3, 1259. [CrossRef]

26. Cho, E.H.; Wendel, M.; Luttgen, M.; Yoshioka, C.; Marrinucci, D.; Lazar, D.; Schram, E.; Nieva, J.; Bazhenova, L.; Morgan, A.; et al. Characterization of circulating tumor cell aggregates identified in patients with epithelial tumors. Phys. Biol. $2012,9,016001$. [CrossRef]

27. Gkountela, S.; Castro-Giner, F.; Szczerba, B.M.; Vetter, M.; Landin, J.; Scherrer, R.; Krol, I.; Scheidmann, M.C.; Beisel, C.; Stirnimann, C.U. Circulating tumor cell clustering shapes DNA methylation to enable metastasis seeding. Cell 2019, 176, 98-112.e114. [CrossRef]

28. Duda, D.G.; Duyverman, A.M.; Kohno, M.; Snuderl, M.; Steller, E.J.; Fukumura, D.; Jain, R.K. Malignant cells facilitate lung metastasis by bringing their own soil. Proc. Natl. Acad. Sci. USA 2010, 107, 21677-21682. [CrossRef]

29. Sprouse, M.L.; Welte, T.; Boral, D.; Liu, H.N.; Yin, W.; Vishnoi, M.; Goswami-Sewell, D.; Li, L.; Pei, G.; Jia, P. PMN-MDSCs enhance CTC metastatic properties through reciprocal interactions via ROS/Notch/Nodal signaling. Int. J. Mol. Sci. 2019, 20, 1916. [CrossRef]

30. Ward, M.P.E.; Kane, L.E.; Norris, L.A.; Mohamed, B.M.; Kelly, T.; Bates, M.; Clarke, A.; Brady, N.; Martin, C.M.; Brooks, R.D.; et al. Platelets, immune cells and the coagulation cascade; friend or foe of the circulating tumour cell? Mol. Cancer 2021, 20, 59. [CrossRef]

31. Placke, T.; Örgel, M.; Schaller, M.; Jung, G.; Rammensee, H.G.; Kopp, H.G.; Salih, H.R. Platelet-derived MHC class I confers a pseudonormal phenotype to cancer cells that subverts the antitumor reactivity of natural killer immune cells. Cancer Res. 2012, 72, 440-448. [CrossRef] [PubMed]

32. Chivukula, V.K.; Krog, B.L.; Nauseef, J.T.; Henry, M.D.; Vigmostad, S.C. Alterations in cancer cell mechanical properties after fluid shear stress exposure: A micropipette aspiration study. Cell Health Cytoskelet. 2015, 7, 25. [PubMed]

33. Nierodzik, M.; Plotkin, A.; Kajumo, F.; Karpatkin, S. Thrombin stimulates tumor-platelet adhesion in vitro and metastasis in vivo. J. Clin. Investig. 1991, 87, 229-236. [CrossRef] [PubMed]

34. Hamm, A.; Prenen, H.; Van Delm, W.; Di Matteo, M.; Wenes, M.; Delamarre, E.; Schmidt, T.; Weitz, J.; Sarmiento, R.; Dezi, A.; et al. Tumour-educated circulating monocytes are powerful candidate biomarkers for diagnosis and disease follow-up of colorectal cancer. Gut 2016, 65, 990-1000. [CrossRef]

35. De Giorgi, U.; Mego, M.; Scarpi, E.; Giordano, A.; Giuliano, M.; Valero, V.; Alvarez, R.H.; Ueno, N.T.; Cristofanilli, M.; Reuben, J.M. Association between circulating tumor cells and peripheral blood monocytes in metastatic breast cancer. Adv. Med. Oncol. 2019, 11, 1758835919866065. [CrossRef]

36. Hurtado, P.; Martínez-Pena, I.; Piñeiro, R. Dangerous Liaisons: Circulating Tumor Cells (CTCs) and Cancer-Associated Fibroblasts (CAFs). Cancers 2020, 12, 2861. [CrossRef]

37. Hamilton, G.; Rath, B.; Klameth, L.; Hochmair, M.J. Small cell lung cancer: Recruitment of macrophages by circulating tumor cells. Oncoimmunology 2016, 5, e1093277. [CrossRef]

38. Hamilton, G.; Rath, B. Circulating tumor cell interactions with macrophages: Implications for biology and treatment. Transl. Lung Cancer Res. 2017, 6, 418-430. [CrossRef] 
39. Gast, C.E.; Silk, A.D.; Zarour, L.; Riegler, L.; Burkhart, J.G.; Gustafson, K.T.; Parappilly, M.S.; Roh-Johnson, M.; Goodman, J.R.; Olson, B. Cell fusion potentiates tumor heterogeneity and reveals circulating hybrid cells that correlate with stage and survival. Sci. Adv. 2018, 4, eaat7828. [CrossRef]

40. Singec, I.; Snyder, E.Y. Inflammation as a matchmaker: Revisiting cell fusion. Nat. Cell Biol. 2008, 10, 503-505. [CrossRef]

41. Lizier, M.; Anselmo, A.; Mantero, S.; Ficara, F.; Paulis, M.; Vezzoni, P.; Lucchini, F.; Pacchiana, G. Fusion between cancer cells and macrophages occurs in a murine model of spontaneous neu+ breast cancer without increasing its metastatic potential. Oncotarget 2016, 7, 60793. [CrossRef] [PubMed]

42. Stanton, S.E.; Adams, S.; Disis, M.L. Variation in the incidence and magnitude of tumor-infiltrating lymphocytes in breast cancer subtypes: A systematic review. JAMA Oncol. 2016, 2, 1354-1360. [CrossRef] [PubMed]

43. Dittmar, T.; Zänker, K.S. Tissue regeneration in the chronically inflamed tumor environment: Implications for cell fusion driven tumor progression and therapy resistant tumor hybrid cells. Int. J. Mol. Sci. 2015, 16, 30362-30381. [CrossRef] [PubMed]

44. Adams, D.; Adams, D.K.; Lin, S.H.; Cristofanilli, M.; Bergan, R.C.; Marks, J.R.; Martin, S.S.; Chumsri, S.; Ho, T.H.; Lapidus, R.G.; et al. Cancer-associated macrophage-like cells as prognostic indicators of overall survival in a variety of solid malignancies. J. Clin. Oncol. 2017, 35, 11503. [CrossRef]

45. Hao, S.-J.; Wan, Y.; Xia, Y.-Q.; Zou, X.; Zheng, S.-Y. Size-based separation methods of circulating tumor cells. Adv, Drug Deliv. Rev. 2018, 125, 3-20. [CrossRef] [PubMed]

46. Tang, C.M.; Zhu, P.; Li, S.; Makarova, O.V.; Amstutz, P.T.; Adams, D.L. Blood-based biopsies—clinical utility beyond circulating tumor cells. Cytom. Part A 2018, 93, 1246-1250. [CrossRef]

47. Eger, A.; Mikulits, W. Models of epithelial-mesenchymal transition. Drug Discov. Today: Dis. Models 2005, 2, 57-63. [CrossRef]

48. Nguyen, D.X.; Bos, P.D.; Massague, J. Metastasis: From dissemination to organ-specific colonization. Nat. Rev. Cancer 2009, 9 , 274-284. [CrossRef]

49. Lambert, A.W.; Pattabiraman, D.R.; Weinberg, R.A. Emerging Biological Principles of Metastasis. Cell 2017, 168, 670-691. [CrossRef]

50. Mohme, M.; Riethdorf, S.; Pantel, K. Circulating and disseminated tumour cells-mechanisms of immune surveillance and escape. Nat. Rev. Clin. Oncol. 2017, 14, 155-167. [CrossRef]

51. Bekes, E.M.; Schweighofer, B.; Kupriyanova, T.A.; Zajac, E.; Ardi, V.C.; Quigley, J.P.; Deryugina, E.I. Tumor-recruited neutrophils and neutrophil TIMP-free MMP-9 regulate coordinately the levels of tumor angiogenesis and efficiency of malignant cell intravasation. Am. J. Pathol. 2011, 179, 1455-1470. [CrossRef] [PubMed]

52. Cools-Lartigue, J.; Spicer, J.; Najmeh, S.; Ferri, L. Neutrophil extracellular traps in cancer progression. Cell Mol. Life Sci. 2014, 71, 4179-4194. [CrossRef] [PubMed]

53. Yang, L.; Liu, Q.; Zhang, X.; Liu, X.; Zhou, B.; Chen, J.; Huang, D.; Li, J.; Li, H.; Chen, F.; et al. DNA of neutrophil extracellular traps promotes cancer metastasis via CCDC25. Nature 2020, 583, 133-138. [CrossRef] [PubMed]

54. Wen, L.; Guo, L.P.; Zhang, W.; Li, Y.J.; Jiang, W.X.; Di, X.B.; Ma, J.H.; Feng, L.; Zhang, K.T.; Shou, J.Z. Cooperation Between the Inflammation and Coagulation Systems Promotes the Survival of Circulating Tumor Cells in Renal Cell Carcinoma Patients. Front. Oncol. 2019, 9. [CrossRef]

55. Santos, M.F.; Mannam, V.K.; Craft, B.S.; Puneky, L.V.; Sheehan, N.T.; Lewis, R.E.; Cruse, J.M. Comparative analysis of innate immune system function in metastatic breast, colorectal, and prostate cancer patients with circulating tumor cells. Exp. Mol. Pathol. 2014, 96, 367-374. [CrossRef]

56. Hanna, N. Role of natural killer cells in control of cancer metastasis. Cancer Metastasis Rev. 1982, 1, 45-64. [CrossRef]

57. Hanna, N.; Fidler, I.J. Role of natural killer cells in the destruction of circulating tumor emboli. J. Natl. Cancer Inst. 1980, 65, 801-809. [CrossRef]

58. Wyckoff, J.B.; Wang, Y.; Lin, E.Y.; Li, J.F.; Goswami, S.; Stanley, E.R.; Segall, J.E.; Pollard, J.W.; Condeelis, J. Direct visualization of macrophage-assisted tumor cell intravasation in mammary tumors. Cancer Res. 2007, 67, 2649-2656. [CrossRef]

59. Harney, A.S.; Arwert, E.N.; Entenberg, D.; Wang, Y.; Guo, P.; Qian, B.Z.; Oktay, M.H.; Pollard, J.W.; Jones, J.G.; Condeelis, J.S. Real-Time Imaging Reveals Local, Transient Vascular Permeability, and Tumor Cell Intravasation Stimulated by TIE2hi Macrophage-Derived VEGFA. Cancer Discov. 2015, 5, 932-943. [CrossRef]

60. Ginter, P.S.; Karagiannis, G.S.; Entenberg, D.; Lin, Y.; Condeelis, J.; Jones, J.G.; Oktay, M.H. Tumor Microenvironment of Metastasis (TMEM) Doorways Are Restricted to the Blood Vessel Endothelium in Both Primary Breast Cancers and Their Lymph Node Metastases. Cancers 2019, 11, 1507. [CrossRef]

61. Kitamura, T.; Qian, B.Z.; Pollard, J.W. Immune cell promotion of metastasis. Nat. Rev. Immunol. 2015, 15, 73-86. [CrossRef] [PubMed]

62. Jiang, W.G.; Sanders, A.J.; Katoh, M.; Ungefroren, H.; Gieseler, F.; Prince, M.; Thompson, S.K.; Zollo, M.; Spano, D.; Dhawan, P.; et al. Tissue invasion and metastasis: Molecular, biological and clinical perspectives. Semin. Cancer Biol. 2015, S244-S275. [CrossRef] [PubMed]

63. Roussos, E.T.; Balsamo, M.; Alford, S.K.; Wyckoff, J.B.; Gligorijevic, B.; Wang, Y.; Pozzuto, M.; Stobezki, R.; Goswami, S.; Segall, J.E.; et al. Mena invasive (MenaINV) promotes multicellular streaming motility and transendothelial migration in a mouse model of breast cancer. J. Cell Sci. 2011, 124, 2120-2131. [CrossRef] [PubMed]

64. Condeelis, J.; Pollard, J.W. Macrophages: Obligate partners for tumor cell migration, invasion, and metastasis. Cell 2006, 124, 263-266. [CrossRef] [PubMed] 
65. Headley, M.B.; Bins, A.; Nip, A.; Roberts, E.W.; Looney, M.R.; Gerard, A.; Krummel, M.F. Visualization of immediate immune responses to pioneer metastatic cells in the lung. Nature 2016, 531, 513-517. [CrossRef]

66. Tan, W.; Zhang, W.; Strasner, A.; Grivennikov, S.; Cheng, J.Q.; Hoffman, R.M.; Karin, M. Tumour-infiltrating regulatory T cells stimulate mammary cancer metastasis through RANKL-RANK signalling. Nature 2011, 470, 548-553. [CrossRef]

67. DeNardo, D.G.; Barreto, J.B.; Andreu, P.; Vasquez, L.; Tawfik, D.; Kolhatkar, N.; Coussens, L.M. CD4(+) T cells regulate pulmonary metastasis of mammary carcinomas by enhancing protumor properties of macrophages. Cancer Cell 2009, 16, 91-102. [CrossRef]

68. Tian, L.; Goldstein, A.; Wang, H.; Ching Lo, H.; Sun Kim, I.; Welte, T.; Sheng, K.; Dobrolecki, L.E.; Zhang, X.; Putluri, N.; et al. Mutual regulation of tumour vessel normalization and immunostimulatory reprogramming. Nature 2017, 544, 250-254. [CrossRef]

69. Joseph, R.; Soundararajan, R.; Vasaikar, S.; Yang, F.; Allton, K.L.; Tian, L.; den Hollander, P.; Isgandarova, S.; Haemmerle, M.; Mino, B.; et al. CD8(+) T cells inhibit metastasis and CXCL4 regulates its function. Br. J. Cancer 2021, 125, 176-189. [CrossRef]

70. Paoli, P.; Giannoni, E.; Chiarugi, P. Anoikis molecular pathways and its role in cancer progression. Biochim. Et Biophys. Acta 2013, 1833. [CrossRef]

71. Luzzi, K.J.; MacDonald, I.C.; Schmidt, E.E.; Kerkvliet, N.; Morris, V.L.; Chambers, A.F.; Groom, A.C. Multistep nature of metastatic inefficiency: Dormancy of solitary cells after successful extravasation and limited survival of early micrometastases. Am. J. Pathol. 1998, 153, 865-873. [CrossRef]

72. Strilic, B.; Offermanns, S. Intravascular Survival and Extravasation of Tumor Cells. Cancer Cell 2017, 32, 282-293. [CrossRef] [PubMed]

73. Wang, W.-C.; Zhang, X.-F.; Peng, J.; Li, X.-F.; Wang, A.-L.; Bie, Y.-Q.; Shi, L.-H.; Lin, M.-B.; Zhang, X.-F. Survival Mechanisms and Influence Factors of Circulating Tumor Cells. BioMed Res. Int. 2018, 2018, 6304701. [CrossRef] [PubMed]

74. Zhong, X.; Zhang, H.; Zhu, Y.; Liang, Y.; Yuan, Z.; Li, J.; Li, J.; Li, X.; Jia, Y.; He, T.; et al. Circulating tumor cells in cancer patients: Developments and clinical applications for immunotherapy. Mol. Cancer 2020, 19, 15. [CrossRef] [PubMed]

75. Iriondo, O.; Yu, M. Unexpected Friendship: Neutrophils Help Tumor Cells En Route to Metastasis. Dev. Cell 2019, 49, 308-310. [CrossRef]

76. Granot, Z.; Henke, E.; Comen, E.A.; King, T.A.; Norton, L.; Benezra, R. Tumor Entrained Neutrophils Inhibit Seeding in the Premetastatic Lung. Cancer Cell 2011, 20, 300-314. [CrossRef]

77. Masucci, M.T.; Minopoli, M.; Carriero, M.V. Tumor Associated Neutrophils. Their Role in Tumorigenesis, Metastasis, Prognosis and Therapy. Front. Oncol. 2019, 9. [CrossRef]

78. Grosse-Steffen, T.; Giese, T.; Giese, N.; Longerich, T.; Schirmacher, P.; Hänsch, G.M.; Gaida, M.M. Epithelial-to-mesenchymal transition in pancreatic ductal adenocarcinoma and pancreatic tumor cell lines: The role of neutrophils and neutrophil-derived elastase. Clin. Dev. Immunol. 2012, 2012, 720768. [CrossRef]

79. Yan, M.; Jurasz, P. The role of platelets in the tumor microenvironment: From solid tumors to leukemia. Biochim Biophys Acta 2016, 1863, 392-400. [CrossRef]

80. Ramasamy, S.; Saez, B.; Mukhopadhyay, S.; Ding, D.; Ahmed, A.M.; Chen, X.; Pucci, F.; Yamin, R.; Wang, J.; Pittet, M.J.; et al. Tle1 tumor suppressor negatively regulates inflammation in vivo and modulates NF-kB inflammatory pathway. Proc. Natl. Acad. Sci. USA 2016, 113, 1871-1876. [CrossRef]

81. Guo, B.; Oliver, T.G. Partners in Crime: Neutrophil-CTC Collusion in Metastasis. Trends Immunol 2019, 40, 556-559. [CrossRef] [PubMed]

82. Taftaf, R.; Liu, X.; Singh, S.; Jia, Y.; Dashzeveg, N.K.; Hoffmann, A.D.; El-Shennawy, L.; Ramos, E.K.; Adorno-Cruz, V.; Schuster, E.J.; et al. ICAM1 initiates CTC cluster formation and trans-endothelial migration in lung metastasis of breast cancer. Nat. Commun. 2021, 12, 4867. [CrossRef] [PubMed]

83. Najmeh, S.; Cools-Lartigue, J.; Rayes, R.; Gowing, S.; Vourtzoumis, P.; Bourdeau, F.; Giannias, B.; Berube, J.; Rousseau, S.; Ferri, L.; et al. Neutrophil Extracellular Traps sequester circulating tumor cells via $\beta 1$-integrin mediated interactions: NETs sequester CTCs via integrin $\beta 1$. Int. J. Cancer 2017, 140. [CrossRef]

84. Canè, S.; Ugel, S.; Trovato, R.; Marigo, I.; De Sanctis, F.; Sartoris, S.; Bronte, V. The Endless Saga of Monocyte Diversity. Front. Immunol. 2019, 10. [CrossRef] [PubMed]

85. Shibuya, T.; Kamiyama, A.; Sawada, H.; Kikuchi, K.; Maruyama, M.; Sawado, R.; Ikeda, N.; Asano, K.; Kurotaki, D.; Tamura, T.; et al. Immunoregulatory Monocyte Subset Promotes Metastasis Associated With Therapeutic Intervention for Primary Tumor. Front. Immunol. 2021, 12, 663115. [CrossRef]

86. Jiang, Z.; Sun, H.; Yu, J.; Tian, W.; Song, Y. Targeting CD47 for cancer immunotherapy. J. Hematol. Oncol. 2021, 14, 180. [CrossRef] [PubMed]

87. Lin, Y.; Xu, J.; Lan, H. Tumor-associated macrophages in tumor metastasis: Biological roles and clinical therapeutic applications. J. Hematol. Oncol. 2019, 12, 76. [CrossRef]

88. Ge, Z.; Ding, S. The Crosstalk Between Tumor-Associated Macrophages (TAMs) and Tumor Cells and the Corresponding Targeted Therapy. Front. Oncol. 2020, 10. [CrossRef]

89. Chalfin, H.J.; Pramparo, T.; Mortazavi, A.; Niglio, S.A.; Schonhoft, J.D.; Jendrisak, A.; Chu, Y.L.; Richardson, R.; Krupa, R.; Anderson, A.K.L.; et al. Circulating Tumor Cell Subtypes and T-cell Populations as Prognostic Biomarkers to Combination Immunotherapy in Patients with Metastatic Genitourinary Cancer. Clin. Cancer Res. 2021, 27, 1391-1398. [CrossRef]

90. Kloten, V.; Lampignano, R.; Krahn, T.; Schlange, T. Circulating Tumor Cell PD-L1 Expression as Biomarker for Therapeutic Efficacy of Immune Checkpoint Inhibition in NSCLC. Cells 2019, 8, 809. [CrossRef] 
91. Kotsakis, A.; Kallergi, G.; Aggouraki, D.; Lyristi, Z.; Koinis, F.; Lagoudaki, E.; Koutsopoulos, A.; Georgoulias, V.; Vetsika, E.K. CD8(+) PD-1(+) T-cells and PD-L1(+) circulating tumor cells in chemotherapy-naïve non-small cell lung cancer: Towards their clinical relevance? Adv. Med. Oncol. 2019, 11, 1758835919853193. [CrossRef] [PubMed]

92. Gruber, I.; Landenberger, N.; Staebler, A.; Hahn, M.; Wallwiener, D.; Fehm, T. Relationship between circulating tumor cells and peripheral T-cells in patients with primary breast cancer. Anticancer Res. 2013, 33, 2233-2238. [PubMed]

93. Kondělková, K.; Vokurková, D.; Krejsek, J.; Borská, L.; Fiala, Z.; Ctirad, A. Regulatory T cells (TREG) and their roles in immune system with respect to immunopathological disorders. Acta Med. 2010, 53, 73-77. [CrossRef] [PubMed]

94. Chaudhary, B.; Elkord, E. Regulatory T Cells in the Tumor Microenvironment and Cancer Progression: Role and Therapeutic Targeting. Vaccines 2016, 4, 28. [CrossRef] [PubMed]

95. Taylor, A.; Verhagen, J.; Blaser, K.; Akdis, M.; Akdis, C.A. Mechanisms of immune suppression by interleukin-10 and transforming growth factor-beta: The role of T regulatory cells. Immunology 2006, 117, 433-442. [CrossRef] [PubMed]

96. Sun, Y.-F.; Wu, L.; Liu, S.-P.; Jiang, M.-M.; Hu, B.; Zhou, K.-Q.; Guo, W.; Xu, Y.; Zhong, Y.; Zhou, X.-R.; et al. Dissecting spatial heterogeneity and the immune-evasion mechanism of CTCs by single-cell RNA-seq in hepatocellular carcinoma. Nat. Commun. 2021, 12, 4091. [CrossRef] [PubMed]

97. Pantano, F.; Rossi, E.; Iuliani, M.; Facchinetti, A.; Simonetti, S.; Ribelli, G.; Zoccoli, A.; Vincenzi, B.; Tonini, G.; Zamarchi, R.; et al. Dynamic changes of Receptor activator of nuclear factor- $\kappa \mathrm{B}$ expression in Circulating Tumor Cells during Denosumab predict treatment effectiveness in Metastatic Breast Cancer. Sci. Rep. 2020, 10, 1288. [CrossRef]

98. Mego, M.; Gao, H.; Cohen, E.N.; Anfossi, S.; Giordano, A.; Sanda, T.; Fouad, T.M.; De Giorgi, U.; Giuliano, M.; Woodward, W.A.; et al. Circulating Tumor Cells (CTC) Are Associated with Defects in Adaptive Immunity in Patients with Inflammatory Breast Cancer. J. Cancer 2016, 7, 1095-1104. [CrossRef]

99. Zhou, Y.; Wang, B.; Wu, J.; Zhang, C.; Zhou, Y.; Yang, X.; Zhou, J.; Guo, W.; Fan, J. Association of preoperative EpCAM Circulating Tumor Cells and peripheral Treg cell levels with early recurrence of hepatocellular carcinoma following radical hepatic resection. BMC Cancer 2016, 16, 506. [CrossRef]

100. Pitti, R.M.; Marsters, S.A.; Ruppert, S.; Donahue, C.J.; Moore, A.; Ashkenazi, A. Induction of apoptosis by Apo-2 ligand, a new member of the tumor necrosis factor cytokine family. J. Biol. Chem. 1996, 271, 12687-12690. [CrossRef]

101. Takeda, K.; Hayakawa, Y.; Smyth, M.J.; Kayagaki, N.; Yamaguchi, N.; Kakuta, S.; Iwakura, Y.; Yagita, H.; Okumura, K. Involvement of tumor necrosis factor-related apoptosis-inducing ligand in surveillance of tumor metastasis by liver natural killer cells. Nat. Med. 2001, 7, 94-100. [CrossRef] [PubMed]

102. Twomey, J.D.; Zhang, B. Circulating Tumor Cells Develop Resistance to TRAIL-Induced Apoptosis Through Autophagic Removal of Death Receptor 5: Evidence from an In Vitro Model. Cancers 2019, 11. [CrossRef] [PubMed]

103. Brodbeck, T.; Nehmann, N.; Bethge, A.; Wedemann, G.; Schumacher, U. Perforin-dependent direct cytotoxicity in natural killer cells induces considerable knockdown of spontaneous lung metastases and computer modelling-proven tumor cell dormancy in a HT29 human colon cancer xenograft mouse model. Mol. Cancer 2014, 13, 244. [CrossRef] [PubMed]

104. Lo, H.C.; Xu, Z.; Kim, I.S.; Muscarella, A.; Liu, J.; Hein, S.; Wang, H.; Krupnick, A.; Neilson, J.; Paust, S.; et al. Circulating tumor cell clusters exhibit enhanced immune evasion from natural killer cells. J. Immunol. 2020, 204, 88.18.

105. Lo, H.C.; Xu, Z.; Kim, I.S.; Pingel, B.; Aguirre, S.; Kodali, S.; Liu, J.; Zhang, W.; Muscarella, A.M.; Hein, S.M.; et al. Resistance to natural killer cell immunosurveillance confers a selective advantage to polyclonal metastasis. Nat. Cancer 2020, 1, 709-722. [CrossRef]

106. Perea Paizal, J.; Au, S.H.; Bakal, C. Squeezing through the microcirculation: Survival adaptations of circulating tumour cells to seed metastasis. Br. J. Cancer 2021, 124, 58-65. [CrossRef]

107. Au, S.H.; Storey, B.D.; Moore, J.C.; Tang, Q.; Chen, Y.-L.; Javaid, S.; Sarioglu, A.F.; Sullivan, R.; Madden, M.W.; O’Keefe, R.; et al. Clusters of circulating tumor cells traverse capillary-sized vessels. Proc. Natl. Acad. Sci. USA 2016, 113, 4947. [CrossRef]

108. Juan, S.J.P.; Garcia-Leon, M.J.; Rangel, L.; Goetz, J.G.; Chaffer, C.L. The Complexities of Metastasis. Cancers 2019, 11, 1575. [CrossRef]

109. Li, J.; King, M.R. Adhesion receptors as therapeutic targets for circulating tumor cells. Front. Oncol. 2012, 2, 79. [CrossRef]

110. Gil, C.D.; La, M.; Perretti, M.; Oliani, S.M. Interaction of human neutrophils with endothelial cells regulates the expression of endogenous proteins annexin 1, galectin-1 and galectin-3. Cell Biol. Int. 2006, 30, 338-344. [CrossRef]

111. Wu, Q.D.; Wang, J.H.; Condron, C.; Bouchier-Hayes, D.; Redmond, H.P. Human neutrophils facilitate tumor cell transendothelial migration. Am. J. Physiol. Cell Physiol. 2001, 280, C814-C822. [CrossRef] [PubMed]

112. Lozar, T.; Gersak, K.; Cemazar, M.; Kuhar, C.G.; Jesenko, T. The biology and clinical potential of circulating tumor cells. Radiol. Oncol. 2019, 53, 131-147. [CrossRef] [PubMed]

113. Wettschureck, N.; Strilic, B.; Offermanns, S. Passing the Vascular Barrier: Endothelial Signaling Processes Controlling Extravasation. Physiol. Rev. 2019, 99, 1467-1525. [CrossRef] [PubMed]

114. Kim, H.; Chung, H.; Kim, J.; Choi, D.-H.; Shin, Y.; Kang, Y.G.; Kim, B.-M.; Seo, S.-U.; Chung, S.; Seok, S.H. Macrophages-Triggered Sequential Remodeling of Endothelium-Interstitial Matrix to Form Pre-Metastatic Niche in Microfluidic Tumor Microenvironment. Adv. Sci. 2019, 6, 1900195. [CrossRef]

115. Shemanko, C.; Cong, Y.; Forsyth, A. What Is Breast in the Bone? Int. J. Mol. Sci. 2016, 17, 1764. [CrossRef]

116. Maurizi, A.; Rucci, N. The Osteoclast in Bone Metastasis: Player and Target. Cancers 2018, 10, 218. [CrossRef]

117. Schaller, J.; Agudo, J. Metastatic Colonization: Escaping Immune Surveillance. Cancers 2020, 12. [CrossRef] 
118. Liu, Y.; Gu, Y.; Han, Y.; Zhang, Q.; Jiang, Z.; Zhang, X.; Huang, B.; Xu, X.; Zheng, J.; Cao, X. Tumor Exosomal RNAs Promote Lung Pre-metastatic Niche Formation by Activating Alveolar Epithelial TLR3 to Recruit Neutrophils. Cancer Cell 2016, 30, 243-256. [CrossRef]

119. Coffelt, S.B.; Kersten, K.; Doornebal, C.W.; Weiden, J.; Vrijland, K.; Hau, C.S.; Verstegen, N.J.M.; Ciampricotti, M.; Hawinkels, L.; Jonkers, J.; et al. IL-17-producing $\gamma \delta$ T cells and neutrophils conspire to promote breast cancer metastasis. Nature 2015, 522, 345-348. [CrossRef]

120. Pommier, A.; Anaparthy, N.; Memos, N.; Kelley, Z.L.; Gouronnec, A.; Yan, R.; Auffray, C.; Albrengues, J.; Egeblad, M.; IacobuzioDonahue, C.A.; et al. Unresolved endoplasmic reticulum stress engenders immune-resistant, latent pancreatic cancer metastases. Science 2018, 360. [CrossRef]

121. Dhatchinamoorthy, K.; Colbert, J.D.; Rock, K.L. Cancer Immune Evasion Through Loss of MHC Class I Antigen Presentation. Front. Immunol. 2021, 12. [CrossRef] [PubMed]

122. Nakamura, K.; Smyth, M.J. Immunoediting of cancer metastasis by NK cells. Nat. Cancer 2020, 1, 670-671. [CrossRef] [PubMed]

123. Lee, C.-C.; Lin, J.-C.; Hwang, W.-L.; Kuo, Y.-J.; Chen, H.-K.; Tai, S.-K.; Lin, C.-C.; Yang, M.-H. Macrophage-secreted interleukin-35 regulates cancer cell plasticity to facilitate metastatic colonization. Nat. Commun. 2018, 9, 3763. [CrossRef] [PubMed]

124. Che, J.; Yu, V.; Garon, E.B.; Goldman, J.W.; Di Carlo, D. Biophysical isolation and identification of circulating tumor cells. Lab Chip 2017, 17, 1452-1461. [CrossRef]

125. Miller, M.C.; Robinson, P.S.; Wagner, C.; O'Shannessy, D.J. The Parsortix ${ }^{\mathrm{TM}}$ Cell Separation System-A versatile liquid biopsy platform. Cytom. Part A 2018, 93, 1234-1239. [CrossRef]

126. Desitter, I.; Guerrouahen, B.; Benali-Furet, N.; Wechsler, J.; Jänne, P.; Kuang, Y.; Yanagita, M.; Wang, L.; Berkowitz, J.; Distel, R.; et al. A New Device for Rapid Isolation by Size and Characterization of Rare Circulating Tumor Cells. Anticancer Res. 2011, 31, 427-441.

127. Gupta, V.; Jafferji, I.; Garza, M.; Melnikova, V.O.; Hasegawa, D.K.; Pethig, R.; Davis, D.W. ApoStream( $\left.{ }^{\mathrm{TM}}\right)$, a new dielectrophoretic device for antibody independent isolation and recovery of viable cancer cells from blood. Biomicrofluidics 2012, 6, 24133. [CrossRef]

128. Smith, K.J.; Jana, J.A.; Kaehr, A.; Purcell, E.; Opdycke, T.; Paoletti, C.; Cooling, L.; Thamm, D.H.; Hayes, D.F.; Nagrath, S. Inertial focusing of circulating tumor cells in whole blood at high flow rates using the microfluidic CTCKey ${ }^{\mathrm{TM}}$ device for CTC enrichment. Lab Chip 2021, 21, 3559-3572. [CrossRef]

129. Ramirez, A.B.; U’Ren, L.; Campton, D.E.; Stewart, D.; Nordberg, J.J.; Stilwell, J.L.; Kaldjian, E.P. RareCyte ${ }^{\circledR C T C}$ Analysis Step 1: AccuCyte®Sample Preparation for the Comprehensive Recovery of Nucleated Cells from Whole Blood. Methods Mol. Biol. 2017, $1634,163-172$.

130. Akpe, V.; Kim, T.H.; Brown, C.L.; Cock, I.E. Circulating tumour cells: A broad perspective. J. R. Soc. Interface 2020, 17, 20200065. [CrossRef]

131. Millner, L.M.; Linder, M.W.; Valdes, R., Jr. Circulating tumor cells: A review of present methods and the need to identify heterogeneous phenotypes. Ann. Clin. Lab. Sci. 2013, 43, 295-304. [PubMed]

132. Frithiof, H.; Welinder, C.; Larsson, A.-M.; Rydén, L.; Aaltonen, K. A novel method for downstream characterization of breast cancer circulating tumor cells following CellSearch isolation. J. Transl. Med. 2015, 13, 126. [CrossRef] [PubMed]

133. Miltenyi, S.; Müller, W.; Weichel, W.; Radbruch, A. High gradient magnetic cell separation with MACS. Cytometry 1990, 11, 231-238. [CrossRef] [PubMed]

134. Kirby, B.; Jodari, M.; Loftus, M.; Gakhar, G.; Pratt, E.; Chanel-Vos, C.; Gleghorn, J.; Santana, S.; Liu, H.; Smith, J.; et al. Functional Characterization of Circulating Tumor Cells with a Prostate-Cancer-Specific Microfluidic Device. PLoS ONE 2012, 7, e35976. [CrossRef]

135. Sheng, W.; Ogunwobi, O.O.; Chen, T.; Zhang, J.; George, T.J.; Liu, C.; Fan, Z.H. Capture, release and culture of circulating tumor cells from pancreatic cancer patients using an enhanced mixing chip. Lab Chip 2014, 14, 89-98. [CrossRef]

136. Lopresti, A.; Malergue, F.; Bertucci, F.; Liberatoscioli, M.L.; Garnier, S.; DaCosta, Q.; Finetti, P.; Gilabert, M.; Raoul, J.L.; Birnbaum, D.; et al. Sensitive and easy screening for circulating tumor cells by flow cytometry. JCI Insight 2019, 5, e128180. [CrossRef]

137. López-Riquelme, N.; Minguela, A.; Villar-Permuy, F.; Ciprian, D.; Castillejo, A.; Álvarez-López, M.R.; Soto, J.L. Imaging cytometry for counting circulating tumor cells: Comparative analysis of the CellSearch vs ImageStream systems. Apmis 2013, 121, 1139-1143. [CrossRef]

138. Hsieh, H.B.; Marrinucci, D.; Bethel, K.; Curry, D.N.; Humphrey, M.; Krivacic, R.T.; Kroener, J.; Kroener, L.; Ladanyi, A.; Lazarus, N.; et al. High speed detection of circulating tumor cells. Biosens. Bioelectron. 2006, 21, 1893-1899. [CrossRef]

139. Werner, S.L.; Graf, R.P.; Landers, M.; Valenta, D.T.; Schroeder, M.; Greene, S.B.; Bales, N.; Dittamore, R.; Marrinucci, D. Analytical Validation and Capabilities of the Epic CTC Platform: Enrichment-Free Circulating Tumour Cell Detection and Characterization. J. Circ. Biomark 2015, 4, 3. [CrossRef]

140. Agnoletto, C.; Minotti, L.; Brulle-Soumare, L.; Pasquali, L.; Galasso, M.; Corrà, F.; Baldassari, F.; Judde, J.-G.; Cairo, S.; Volinia, S. Heterogeneous expression of EPCAM in human circulating tumour cells from patient-derived xenografts. Biomark. Res. 2018, 6, 31. [CrossRef]

141. Wang, S.; Zhou, Y.; Qin, X.; Nair, S.; Huang, X.; Liu, Y. Label-free detection of rare circulating tumor cells by image analysis and machine learning. Sci. Rep. 2020, 10, 12226. [CrossRef]

142. Li, Y.; Gong, J.; Zhang, Q.; Lu, Z.; Gao, J.; Li, Y.; Cao, Y.; Shen, L. Dynamic monitoring of circulating tumour cells to evaluate therapeutic efficacy in advanced gastric cancer. Br. J. Cancer 2016, 114, 138-145. [CrossRef] [PubMed] 
143. Goodman, O.B., Jr.; Symanowski, J.T.; Loudyi, A.; Fink, L.M.; Ward, D.C.; Vogelzang, N.J. Circulating Tumor Cells as a Predictive Biomarker in Patients With Hormone-sensitive Prostate Cancer. Clin. Genitourin. Cancer 2011, 9, 31-38. [CrossRef] [PubMed]

144. Liu, J.; Lian, J.; Chen, Y.; Zhao, X.; Du, C.; Xu, Y.; Hu, H.; Rao, H.; Hong, X. Circulating Tumor Cells (CTCs): A Unique Model of Cancer Metastases and Non-invasive Biomarkers of Therapeutic Response. Front. Genet. 2021, 12, 1552. [CrossRef] [PubMed]

145. Balakrishnan, A.; Koppaka, D.; Anand, A.; Deb, B.; Grenci, G.; Viasnoff, V.; Thompson, E.W.; Gowda, H.; Bhat, R.; Rangarajan, A.; et al. Circulating Tumor Cell cluster phenotype allows monitoring response to treatment and predicts survival. Sci. Rep. 2019, 9, 7933. [CrossRef]

146. Zhou, X.; Liu, X.; Huang, L. Macrophage-Mediated Tumor Cell Phagocytosis: Opportunity for Nanomedicine Intervention. Adv. Funct. Mater. 2021, 31, 2006220. [CrossRef]

147. Gül, N.; Babes, L.; Siegmund, K.; Korthouwer, R.; Bögels, M.; Braster, R.; Vidarsson, G.; ten Hagen, T.L.M.; Kubes, P.; van Egmond, M. Macrophages eliminate circulating tumor cells after monoclonal antibody therapy. J. Clin. Investig. 2014, 124, 812-823. [CrossRef]

148. Gül, N.; van Egmond, M. Antibody-Dependent Phagocytosis of Tumor Cells by Macrophages: A Potent Effector Mechanism of Monoclonal Antibody Therapy of Cancer. Cancer Res. 2015, 75, 5008. [CrossRef]

149. Van der Bij, G.J.; Bögels, M.; Otten, M.A.; Oosterling, S.J.; Kuppen, P.J.; Meijer, S.; Beelen, R.H.J.; van Egmond, M. Experimentally induced liver metastases from colorectal cancer can be prevented by mononuclear phagocyte-mediated monoclonal antibody therapy. J. Hepatol. 2010, 53, 677-685. [CrossRef]

150. Lian, S.; Xie, X.; Lu, Y.; Jia, L. Checkpoint CD47 Function On Tumor Metastasis And Immune Therapy. Oncotargets 2019, 12, 9105-9114. [CrossRef]

151. Lian, S.; Xie, R.; Ye, Y.; Lu, Y.; Cheng, Y.; Xie, X.; Li, S.; Jia, L. Dual blockage of both PD-L1 and CD47 enhances immunotherapy against circulating tumor cells. Sci. Rep. 2019, 9, 4532. [CrossRef] [PubMed]

152. Zhang, M.; Hutter, G.; Kahn, S.A.; Azad, T.D.; Gholamin, S.; Xu, C.Y.; Liu, J.; Achrol, A.S.; Richard, C.; Sommerkamp, P.; et al. Anti-CD47 Treatment Stimulates Phagocytosis of Glioblastoma by M1 and M2 Polarized Macrophages and Promotes M1 Polarized Macrophages In Vivo. PLoS ONE 2016, 11, e0153550. [CrossRef] [PubMed]

153. Goto, H.; Kojima, Y.; Matsuda, K.; Kariya, R.; Taura, M.; Kuwahara, K.; Nagai, H.; Katano, H.; Okada, S. Efficacy of anti-CD47 antibody-mediated phagocytosis with macrophages against primary effusion lymphoma. Eur. J. Cancer 2014, 50, 1836-1846. [CrossRef] [PubMed]

154. Li, J.; Sharkey, C.C.; Wun, B.; Liesveld, J.L.; King, M.R. Genetic engineering of platelets to neutralize circulating tumor cells. J. Control. Release 2016, 228, 38-47. [CrossRef] [PubMed]

155. Ortiz-Otero, N.; Marshall, J.R.; Lash, B.W.; King, M.R. Platelet mediated TRAIL delivery for efficiently targeting circulating tumor cells. Nanoscale Adv. 2020, 2, 3942-3953. [CrossRef]

156. Mitchell, M.J.; Wayne, E.; Rana, K.; Schaffer, C.B.; King, M.R. TRAIL-coated leukocytes that kill cancer cells in the circulation Proc. Natl. Acad. Sci. USA 2014, 111, 930-935. [CrossRef]

157. Qin, D.; Li, D.; Zhang, B.; Chen, Y.; Liao, X.; Li, X.; Alexander, P.B.; Wang, Y.; Li, Q.-J. Potential lung attack and lethality generated by EpCAM-specific CAR-T cells in immunocompetent mouse models. Oncoimmunology 2020, 9, 1806009. [CrossRef]

158. Zhang, Y.; Zhang, Z. The history and advances in cancer immunotherapy: Understanding the characteristics of tumor-infiltrating immune cells and their therapeutic implications. Cell Mol. Immunol. 2020, 17, 807-821. [CrossRef]

159. Danila, D.C.; Pantel, K.; Fleisher, M.; Scher, H.I. Circulating tumors cells as biomarkers: Progress toward biomarker qualification. Cancer J. 2011, 17, 438-450. [CrossRef]

160. Lim, S.B.; Di Lee, W.; Vasudevan, J.; Lim, W.-T.; Lim, C.T. Liquid biopsy: One cell at a time. NPJ Precis. Oncol. 2019, 3, 23. [CrossRef]

161. Riethdorf, S.; O'Flaherty, L.; Hille, C.; Pantel, K. Clinical applications of the CellSearch platform in cancer patients. Adv. Drug Deliv. Rev. 2018, 125, 102-121. [CrossRef] [PubMed]

162. Klein, C.A. Parallel progression of primary tumours and metastases. Nat. Rev. Cancer 2009, 9, 302-312. [CrossRef] [PubMed]

163. Ankeny, J.S.; Court, C.M.; Hou, S.; Li, Q.; Song, M.; Wu, D.; Chen, J.F.; Lee, T.; Lin, M.; Sho, S.; et al. Circulating tumour cells as a biomarker for diagnosis and staging in pancreatic cancer. Br. J. Cancer 2016, 114, 1367-1375. [CrossRef] [PubMed]

164. Krol, I.; Schwab, F.D.; Carbone, R.; Ritter, M.; Picocci, S.; De Marni, M.L.; Stepien, G.; Franchi, G.M.; Zanardi, A.; Rissoglio, M.D.; et al. Detection of clustered circulating tumour cells in early breast cancer. Br. J. Cancer 2021, 125, 23-27. [CrossRef]

165. Ried, K.; Eng, P.; Sali, A. Screening for Circulating Tumour Cells Allows Early Detection of Cancer and Monitoring of Treatment Effectiveness: An Observational Study. Asian Pac. J. Cancer Prev.: APJCP 2017, 18, 2275-2285. [CrossRef]

166. Ilie, M.; Hofman, V.; Long-Mira, E.; Selva, E.; Vignaud, J.-M.; Padovani, B.; Mouroux, J.; Marquette, C.-H.; Hofman, P. "Sentinel" circulating tumor cells allow early diagnosis of lung cancer in patients with chronic obstructive pulmonary disease. PLoS ONE 2014, 9, e111597. [CrossRef]

167. Qi, L.-N.; Xiang, B.-D.; Wu, F.-X.; Ye, J.-Z.; Zhong, J.-H.; Wang, Y.-Y.; Chen, Y.-Y.; Chen, Z.-S.; Ma, L.; Chen, J.; et al. Circulating Tumor Cells Undergoing EMT Provide a Metric for Diagnosis and Prognosis of Patients with Hepatocellular Carcinoma. Cancer Res. 2018, 78, 4731. [CrossRef]

168. Thery, L.; Meddis, A.; Cabel, L.; Proudhon, C.; Latouche, A.; Pierga, J.-Y.; Bidard, F.-C. Circulating Tumor Cells in Early Breast Cancer. JNCI Cancer Spectr. 2019, 3. [CrossRef] 
169. D'Avola, D.; Villacorta-Martin, C.; Martins-Filho, S.N.; Craig, A.; Labgaa, I.; von Felden, J.; Kimaada, A.; Bonaccorso, A.; Tabrizian, P.; Hartmann, B.M.; et al. High-density single cell mRNA sequencing to characterize circulating tumor cells in hepatocellular carcinoma. Sci. Rep. 2018, 8, 11570. [CrossRef]

170. Luca, F.D.; Rotunno, G.; Salvianti, F.; Galardi, F.; Pestrin, M.; Gabellini, S.; Simi, L.; Mancini, I.; Vannucchi, A.M.; Pazzagli, M.; et al. Mutational analysis of single circulating tumor cells by next generation sequencing in metastatic breast cancer. Oncotarget 2016, 7 , 26107-26119. [CrossRef]

171. Ting, D.T.; Wittner, B.S.; Ligorio, M.; Jordan, N.V.; Shah, A.M.; Miyamoto, D.T.; Aceto, N.; Bersani, F.; Brannigan, B.W.; Xega, K.; et al. Single-Cell RNA Sequencing Identifies Extracellular Matrix Gene Expression by Pancreatic Circulating Tumor Cells. Cell Rep. 2014, 8, 1905-1918. [CrossRef]

172. Miyamoto David, T.; Zheng, Y.; Wittner Ben, S.; Lee Richard, J.; Zhu, H.; Broderick Katherine, T.; Desai, R.; Fox Douglas, B.; Brannigan Brian, W.; Trautwein, J.; et al. RNA-Seq of single prostate CTCs implicates noncanonical Wnt signaling in antiandrogen resistance. Science 2015, 349, 1351-1356. [CrossRef] [PubMed]

173. Darvin, P.; Toor, S.M.; Sasidharan Nair, V.; Elkord, E. Immune checkpoint inhibitors: Recent progress and potential biomarkers Exp. Mol. Med. 2018, 50,1-11. [CrossRef] [PubMed]

174. Khoja, L.; Lorigan, P.; Zhou, C.; Lancashire, M.; Booth, J.; Cummings, J.; Califano, R.; Clack, G.; Hughes, A.; Dive, C. Biomarker Utility of Circulating Tumor Cells in Metastatic Cutaneous Melanoma. J. Investig. Dermatol. 2013, 133, 1582-1590. [CrossRef] [PubMed]

175. Klinac, D.; Gray, E.S.; Freeman, J.B.; Reid, A.; Bowyer, S.; Millward, M.; Ziman, M. Monitoring changes in circulating tumour cells as a prognostic indicator of overall survival and treatment response in patients with metastatic melanoma. BMC Cancer 2014, 14, 423. [CrossRef] [PubMed]

176. Khattak, M.A.; Gray, E.S.; Reid, A.; Periera, M.; McEvoy, A.; Aya-Bonilla, C.; Meniawy, T.; Didan, A.; Millward, M.; Ziman, M. PD-L1 expression on pre-treatment circulating tumour cells, but not serum VEGF, is predictive of response to pembrolizumab in melanoma. Ann. Oncol. 2018, 29, viii24-viii25. [CrossRef]

177. Yue, C.; Jiang, Y.; Li, P.; Wang, Y.; Xue, J.; Li, N.; Li, D.; Wang, R.; Dang, Y.; Hu, Z.; et al. Dynamic change of PD-L1 expression on circulating tumor cells in advanced solid tumor patients undergoing PD-1 blockade therapy. Oncoimmunology 2018, 7, e1438111. [CrossRef]

178. Lin, S.Y.; Chang, S.-C.; Lam, S.; Irene Ramos, R.; Tran, K.; Ohe, S.; Salomon, M.P.; Bhagat, A.A.S.; Teck Lim, C.; Fischer T.D.; et al. Prospective Molecular Profiling of Circulating Tumor Cells from Patients with Melanoma Receiving Combinatorial Immunotherapy. Clin. Chem. 2020, 66, 169-177. [CrossRef]

179. Hong, X.; Sullivan, R.J.; Kalinich, M.; Kwan, T.T.; Giobbie-Hurder, A.; Pan, S.; LiCausi, J.A.; Milner, J.D.; Nieman, L.T.; Wittner, B.S.; et al. Molecular signatures of circulating melanoma cells for monitoring early response to immune checkpoint therapy. Proc. Natl. Acad. Sci. USA 2018, 115, 2467. [CrossRef]

180. Kallergi, G.; Vetsika, E.-K.; Aggouraki, D.; Lagoudaki, E.; Koutsopoulos, A.; Koinis, F.; Katsarlinos, P.; Trypaki, M.; Messaritakis, I.; Stournaras, C.; et al. Evaluation of PD-L1/PD-1 on circulating tumor cells in patients with advanced non-small cell lung cancer. Adv. Med. Oncol. 2018, 10, 1758834017750121. [CrossRef]

181. Kulasinghe, A.; Kapeleris, J.; Kimberley, R.; Mattarollo, S.R.; Thompson, E.W.; Thiery, J.-P.; Kenny, L.; O’Byrne, K.; Punyadeera, C. The prognostic significance of circulating tumor cells in head and neck and non-small-cell lung cancer. Cancer Med. 2018, 7, 5910-5919. [CrossRef]

182. Nicolazzo, C.; Raimondi, C.; Mancini, M.; Caponnetto, S.; Gradilone, A.; Gandini, O.; Mastromartino, M.; Del Bene, G.; Prete, A.; Longo, F.; et al. Monitoring PD-L1 positive circulating tumor cells in non-small cell lung cancer patients treated with the PD-1 inhibitor Nivolumab. Sci. Rep. 2016, 6, 31726. [CrossRef] [PubMed]

183. Guibert, N.; Delaunay, M.; Lusque, A.; Boubekeur, N.; Rouquette, I.; Clermont, E.; Mourlanette, J.; Gouin, S.; Dormoy, I.; Favre, G.; et al. PD-L1 expression in circulating tumor cells of advanced non-small cell lung cancer patients treated with nivolumab. Lung Cancer 2018, 120, 108-112. [CrossRef] [PubMed]

184. Dhar, M.; Wong, J.; Che, J.; Matsumoto, M.; Grogan, T.; Elashoff, D.; Garon, E.B.; Goldman, J.W.; Sollier Christen, E.; Di Carlo, D.; et al. Evaluation of PD-L1 expression on vortex-isolated circulating tumor cells in metastatic lung cancer. Sci. Rep. 2018, 8 , 2592. [CrossRef] [PubMed]

185. Mazel, M.; Jacot, W.; Pantel, K.; Bartkowiak, K.; Topart, D.; Cayrefourcq, L.; Rossille, D.; Maudelonde, T.; Fest, T.; Alix-Panabières, C. Frequent expression of PD-L1 on circulating breast cancer cells. Mol. Oncol. 2015, 9, 1773-1782. [CrossRef]

186. Schott, D.S.; Pizon, M.; Pachmann, U.; Pachmann, K. Sensitive detection of PD-L1 expression on circulating epithelial tumor cells (CETCs) could be a potential biomarker to select patients for treatment with PD-1/PD-L1 inhibitors in early and metastatic solid tumors. Oncotarget 2017, 8, 72755-72772. [CrossRef]

187. Anantharaman, A.; Friedlander, T.; Lu, D.; Krupa, R.; Premasekharan, G.; Hough, J.; Edwards, M.; Paz, R.; Lindquist, K.; Graf, R.; et al. Programmed death-ligand 1 (PD-L1) characterization of circulating tumor cells (CTCs) in muscle invasive and metastatic bladder cancer patients. BMC Cancer 2016, 16, 744. [CrossRef]

188. Boudadi, K.; Suzman, D.L.; Anagnostou, V.; Fu, W.; Luber, B.; Wang, H.; Niknafs, N.; White, J.R.; Silberstein, J.L.; Sullivan, R.; et al. Ipilimumab plus nivolumab and DNA-repair defects in AR-V7-expressing metastatic prostate cancer. Oncotarget 2018, 9 , 28561-28571. [CrossRef] 
189. Strati, A.; Koutsodontis, G.; Papaxoinis, G.; Angelidis, I.; Zavridou, M.; Economopoulou, P.; Kotsantis, I.; Avgeris, M.; Mazel, M.; Perisanidis, C.; et al. Prognostic significance of PD-L1 expression on circulating tumor cells in patients with head and neck squamous cell carcinoma. Ann. Oncol. 2017, 28, 1923-1933. [CrossRef]

190. Winograd, P.; Hou, S.; Court, C.M.; Lee, Y.-T.; Chen, P.-J.; Zhu, Y.; Sadeghi, S.; Finn, R.S.; Teng, P.-C.; Wang, J.J.; et al. Hepatocellular Carcinoma-Circulating Tumor Cells Expressing PD-L1 Are Prognostic and Potentially Associated With Response to Checkpoint Inhibitors. Hepatol. Commun. 2020, 4, 1527-1540. [CrossRef]

191. Handy, C.E.; Antonarakis, E.S. Sipuleucel-T for the treatment of prostate cancer: Novel insights and future directions. Future Oncol. 2018, 14, 907-917. [CrossRef] [PubMed]

192. Rekoske, B.T.; Olson, B.M.; McNeel, D.G. Antitumor vaccination of prostate cancer patients elicits PD-1/PD-L1 regulated antigen-specific immune responses. Oncoimmunology 2016, 5, e1165377. [CrossRef] [PubMed]

193. Lin, M.; Liang, S.-Z.; Shi, J.; Niu, L.-Z.; Chen, J.-B.; Zhang, M.-J.; Xu, K.-C. Circulating tumor cell as a biomarker for evaluating allogenic NK cell immunotherapy on stage IV non-small cell lung cancer. Immunol. Lett. 2017, 191, 10-15. [CrossRef] [PubMed]

194. Liang, S.; Xu, K.; Niu, L.; Wang, X.; Liang, Y.; Zhang, M.; Chen, J.; Lin, M. Comparison of autogeneic and allogeneic natural killer cells immunotherapy on the clinical outcome of recurrent breast cancer. Oncotargets 2017, 10, 4273-4281. [CrossRef] [PubMed]

195. Genna, A.; Vanwynsberghe, A.M.; Villard, A.V.; Pottier, C.; Ancel, J.; Polette, M.; Gilles, C. EMT-Associated Heterogeneity in Circulating Tumor Cells: Sticky Friends on the Road to Metastasis. Cancers 2020, 12, 1632. [CrossRef]

196. Blass, E.; Ott, P.A. Advances in the development of personalized neoantigen-based therapeutic cancer vaccines. Nat. Rev. Clin. Oncol. 2021, 18, 215-229. [CrossRef]

197. Ott, P.A.; Hu, Z.; Keskin, D.B.; Shukla, S.A.; Sun, J.; Bozym, D.J.; Zhang, W.; Luoma, A.; Giobbie-Hurder, A.; Peter, L.; et al. An immunogenic personal neoantigen vaccine for patients with melanoma. Nature 2017, 547, 217-221. [CrossRef]

198. Carreno, B.M.; Magrini, V.; Becker-Hapak, M.; Kaabinejadian, S.; Hundal, J.; Petti, A.A.; Ly, A.; Lie, W.-R.; Hildebrand, W.H.; Mardis, E.R.; et al. Cancer immunotherapy. A dendritic cell vaccine increases the breadth and diversity of melanoma neoantigenspecific T cells. Science 2015, 348, 803-808. [CrossRef]

199. Hilf, N.; Kuttruff-Coqui, S.; Frenzel, K.; Bukur, V.; Stevanović, S.; Gouttefangeas, C.; Platten, M.; Tabatabai, G.; Dutoit, V.; van der Burg, S.H.; et al. Actively personalized vaccination trial for newly diagnosed glioblastoma. Nature 2019, 565, 240-245. [CrossRef]

200. Jia, Q.; Chiu, L.; Wu, S.; Bai, J.; Peng, L.; Zheng, L.; Zang, R.; Li, X.; Yuan, B.; Gao, Y.; et al. Tracking Neoantigens by Personalized Circulating Tumor DNA Sequencing during Checkpoint Blockade Immunotherapy in Non-Small Cell Lung Cancer. Adv. Sci. 2020, 7, 1903410. [CrossRef]

201. Micalizzi, D.S.; Maheswaran, S.; Haber, D.A. A conduit to metastasis: Circulating tumor cell biology. Genes Dev. 2017, 31, 1827-1840. [CrossRef] [PubMed]

202. Onstenk, W.; Sieuwerts, A.M.; Mostert, B.; Lalmahomed, Z.; Bolt-de Vries, J.B.; van Galen, A.; Smid, M.; Kraan, J.; Van, M.; de Weerd, V.; et al. Molecular characteristics of circulating tumor cells resemble the liver metastasis more closely than the primary tumor in metastatic colorectal cancer. Oncotarget 2016, 7, 59058-59069. [CrossRef] [PubMed]

203. Ko, J.; Baldassano, S.N.; Loh, P.-L.; Kording, K.; Litt, B.; Issadore, D. Machine learning to detect signatures of disease in liquid biopsies-a user's guide. Lab Chip 2018, 18, 395-405. [CrossRef] [PubMed]

204. Lannin, T.B.; Thege, F.I.; Kirby, B.J. Comparison and optimization of machine learning methods for automated classification of circulating tumor cells. Cytom. Part A 2016, 89, 922-931. [CrossRef]

205. Zeune, L.L.; Boink, Y.E.; van Dalum, G.; Nanou, A.; de Wit, S.; Andree, K.C.; Swennenhuis, J.F.; van Gils, S.A.; Terstappen, L.W.M.M.; Brune, C. Deep learning of circulating tumour cells. Nat. Mach. Intell. 2020, 2, 124-133. [CrossRef]

206. Jiao, D.Z.; Li, D.H.; Xiao, P.Y.; Dorsey, D.J.; Simone, D.C.B.; Feigenberg, P.S.; Kao, D.G.; Fan, D.Y. Integration of deep learning radiomics and counts of circulating tumor cells improves prediction of outcomes of early stage NSCLC patients treated with SBRT. Int. J. Radiat. Oncol. Biol. Phys. 2021. 